\title{
Cancer Genetics and Epigenetics in Cancer Risk Assesment
}

\author{
Anna Meiliana ${ }^{1,2,3}$, Nurrani Mustika Dewi ${ }^{1,3}$, Andi Wijaya ${ }^{1,2,3}$ \\ ${ }^{1}$ Prodia Clinical Laboratory, Bandung, Indonesia \\ ${ }^{2}$ Post Graduate Program in Clinical Pharmacy, Faculty of Pharmacy, Padjadjaran University, Bandung, Indonesia \\ ${ }^{3}$ Prodia Education and Research Institute, Jakarta, Indonesia
}

\begin{abstract}
Compared to the normal tissues, cancer cells tend to have higher proliferation rate and often lost their ability to undergo apoptosis. In addition, cancer cells can separate themselves from their original tissue thus causing metastasis in other part of body. While undergoing program cell death, disordered cellular programming can happen. The main causes of this cellular programming anomaly are epigenetic and genetic alterations, which have been known as two separate mechanisms in carcinogenetic. A recent outcome of whole exome sequencing of thousands of human cancers has been the unexpected discovery of many inactivating mutations in genes that control the epigenome. These mutations have the potential to disturb the DNA methylation patterns, histone modifications, and nucleosome positioning, hence, the causing gene expression alternation. Genetic alteration of the epigenome therefore contributes to cancer just as epigenetic process can cause point mutations and disable DNA repair functions. Epigenetic mechanisms changes could cause genetic mutations, and genetic mutations in epigenetic regulators could cause epigenome changes. Knowing that epigenome play a major role in the hierarchy of gene control mechanisms suggests that mutations might have impact on multiple pathways related to cancer phenotype. This pinpoint the fact that recently, the way the genes are organized and controlled are suggested to be a relevant factor for human carcinogenesis.
\end{abstract}

Keywords: cancer genetic, cancer epigenetic, oncogens, tumor suppressor genes, driver mutation, passenger mutation

\section{Introduction}

Cancer can turns into various different forms depending on the location, cell of origin and spectrum of genomic changes that promote oncogenesis and affect therapeutic response. ${ }^{1}$ It is already well known that cancer is fundamentally a genomic disease. Early on, large numbers of oncogenes were identified using functional assays on genetic material from tumors in positive-selection systems ${ }^{2-4}$, and a subset of tumor suppressor genes was identified by analyzing loss of heterozygosity ${ }^{5}$. More recently, systematic cancer genomics projects, including The Cancer Genome Atlas (TCGA), have applied emerging technologies to the analysis of specific tumor types. This disease-specific focus has identified novel oncogenic drivers and the genes contributing to functional change $\mathrm{e}^{6-8}$, has established definitions of molecular subtypes $^{9-13}$, and has identified new biomarkers based on the genomic, transcriptomic, proteomic and epigenomic alterations. Some of these biomarkers have clinical implications..$^{14,15}$ 
Rising numbers of tumor sample data sets enhance the ability to detect and analyze molecular defects in cancers. For example, driver genes can be pinpointed more precisely by narrowing regions affected by amplification and deletion to smaller segments of the chromosome using data on recurrent events across tumor types. The use of large cohorts has enabled DNA sequencing to uncover a list of recurrent genomic aberrations (mutations, amplifications, deletions, translocations, fusions and other structural variants), both known and novel, as common events across tumor types. ${ }^{16}$

Cancer has been long known as a disease caused by the accumulation of genetic mutations. ${ }^{17}$ However, this paradigm has now been expanded to incorporate the disruption of epigenetic regulatory mechanisms that are prevalent in cancer. ${ }^{18,19}$ Abnormal gene function and patterns change in gene expression are the main points of cancer. Many evidence shows that acquired epigenetic abnormalities are involved in genetic alterations to cause this dysregulation. ${ }^{20}$

Given the importance of epigenetic silencing in the development of cancer, distinguishing the driver genes and the passenger genes is becoming an important priority for the field. Driver genes must be essential for cancer causation, whereas passenger genes are not necessary. ${ }^{21}$ With the improvement of technology, it may eventually be possible to specifically distinguish epigenetic disruptions of the driver genes. ${ }^{22,23}$ Current evidence shows that epigenetic disruption plays a key role at every stage of tumorigenesis and has a significant impact on the underlying mechanisms of tumorigenesis and development of cancer therapy. ${ }^{24}$ Rare, large families with multiple cases of early-onset cancer affecting several generations provide clear evidence that inherited factors are important causes of cancer. ${ }^{25}$ Family history is an important risk factor in almost all cancers, but most familial cancers are not caused by mutations in the rare tumor-suppressor genes described above. Other, lower-risk (less penetrant) genes must be present. Detecting them requires genetic strategies other than linkage analysis, because they do not confer a high enough risk of cancer to cause a noticeable accumulation of cancers in a family. ${ }^{26,27}$

The identification of high-risk cancer susceptibility genes means that physicians and persons at risk must understand the implications of the risk of genetic cancer; this identification has resulted in the blossoming of cancer genetics as a clinical subspecialty. Genetic counselors and other health specialists with expertise in cancer risk assessment are qualified to offer the kinds of services needed by persons with or at risk for hereditary cancer. ${ }^{27}$ Combined knowledge of inherited and acquired genetic changes is likely to result in significant advances in the prevention, diagnosis, and treatment of the five most common cancers, which are responsible for more than half of all cancerrelated deaths. ${ }^{27}$

\section{Cancer Genome Landscape}

Over the past decade, comprehensive sequencing efforts have revealed the genomic landscapes of common forms of human cancer. For most cancer types, this landscape consists of a small number of "mountains" (genes altered in a high percentage of tumors) and a much larger number of "hills" (genes altered infrequently). To date, these studies have revealed $\sim 140$ genes that, when altered by intragenic mutations, can promote or "drive" tumorigenesis. A typical tumor contains two to eight of these "driver gene" mutations; the remaining mutations are passengers that confer no selective growth advantage. Driver genes can be classified into 12 signaling pathways that regulate three core cellular processes, which are cell fate, cell survival, and genome maintenance. ${ }^{16}$

Genomic instability (GIN) has been highlighted as a driving force of tumorigenesis by Hanahan and Weinberg in their celebrated "Hallmarks of Cancer" article. ${ }^{16}$ GIN can result from changes in the number or structure of chromosomes (chromosomal instability), changes in the number of oligonucleotide repeats in microsatellite sequences (microsatellite instability), or base pair mutations, all of which are associated with activated oncogenes. Figure 1 shows some somatic mutations in representative human cancers which detected by genome-wide sequencing studies. Deregulation of DNA replication, known as replication stress (RS), is linked to GIN and is increased during the early steps of carcinogenesis. ${ }^{28-30}$ In particular, RS has been associated with chromosomal instability ${ }^{31}$ as well as activation of the apolipoprotein B mRNA editing enzyme catalytic polypeptide-like 3 (APOBEC3) family of deaminases ${ }^{32}$, which increase the mutagenic load that fuels tumorigenesis. DNA replication ensures the precise duplication of DNA during each cell cycle. It is a tightly regulated process that consists of two stages: licensing and initiation. ${ }^{33}$ In eukaryotic cells, the licensing stage is restricted during late mitosis and G1-phase when thousands of replication origins are established along the genome and 


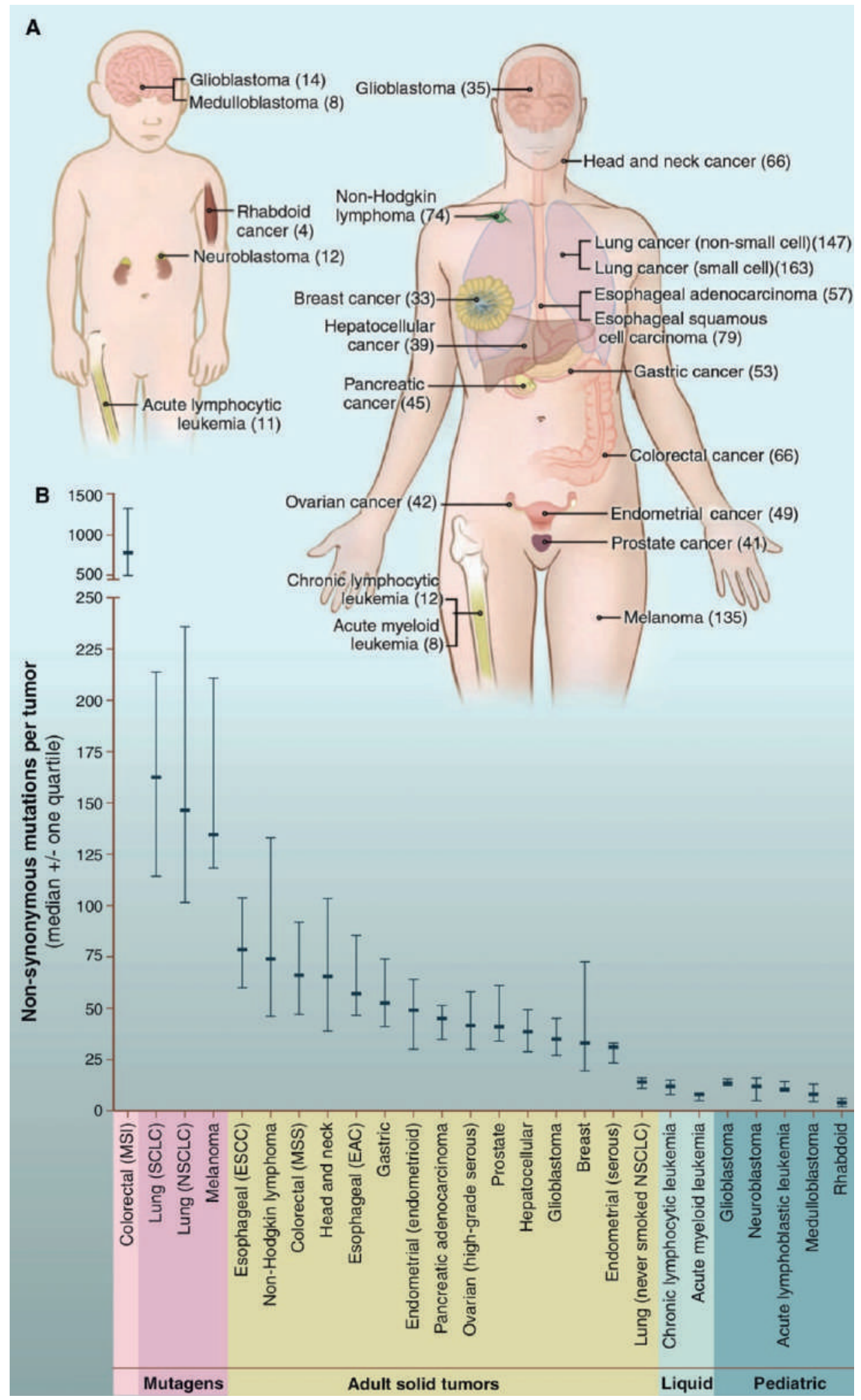

Figure 1. Number of somatic mutations in representative human cancers, detected by genome-wide sequencing studies. A: The genomes of a diverse group of adult (right) and pediatric (left) cancers have been analyzed. Numbers in parentheses indicate the median number of nonsynonymous mutations per tumor. B: The median number of nonsynonymous mutations per tumor in a variety of tumor types.(16) (Adapted with permission from The American Association for the Advancement of Science). 
ensures that DNA replication occurs only once per cell

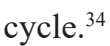

Replication is susceptible to impediments in DNA caused by both exogenous and endogenous DNA-damaging agents and by the intrinsic properties of certain DNA sequences to adopt secondary structures. In particular, fork progression can be hindered due to interference with the transcription machinery, torsional stress or non-B DNA

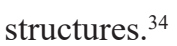

Normal cells become cancerous through a complex process known as oncogenic transformation. Transformation is driven by altered expression of oncogenes, tumor suppressors, or miRNAs that derail their normal physiologic function..$^{35} \mathrm{~A}$ protooncogene is a gene that under unperturbed conditions generally encodes a protein implicated in cell growth, differentiation, or apoptosis. Either through point mutation, chromosomal translocation, or copynumber amplification, expression of the protooncogene is misregulated, resulting in an activated oncogene. Oncogenes are translated into oncoproteins, which are classified as growth factors, growth factor receptors, transcription factors, signal transducers, chromatin remodelers, and apoptosis regulators. As such, oncogene activation may cause massive changes in the genome by deregulating cell cycle, metabolism, replication timing, or transcription, which ultimately drive GIN. ${ }^{34}$

Apoptosis and senescence act as protective mechanisms that eliminate or halt cells that present with RS and/or GIN. This cancer protection barrier is quite robust, as affirmed by the fact that expression of oncogenes alone does not lead to oncogenic transformation unless combined with other genetic events, most notably additional expression of other oncogenes or mutation of tumor suppressor genes. ${ }^{36-38}$ Oncogene-induced senescence is ascribed to the actions of the tumor suppressor p53 and its positive regulator p14/ p19 (ARF). ARF inhibits the ubiquitin ligase mouse double minute 2 homolog (MDM2) that is normally responsible for p53 degradation, thereby stabilizing p53 levels. Among other oncogenes, p53 is activated in response to Ras, c-MYC, E1A, and Signal transducer and activator of transcription 5A (STAT5A) overexpression either directly through ARF or RS-induced Ataxia telangiectasia mutated (ATM) activation. In addition, the oncogenes Ras, MYC, $\mathrm{E} 2 \mathrm{~F} 1$, and $\beta$-Catenin and the adenovirus E1 $\mathrm{A}$ have been shown to upregulate ARF, whereas c-MYC causes ARF stabilization by inhibiting its ubiquitylation and subsequent degradation by ubiquitin ligase for ARF (ULF) ${ }^{39}$
Determining whether rare aberrations are drivers (oncogenic contributors) or just passengers (clonally propagated with neutral effect) and whether they are clinically actionable will require further functional evaluation as well as the analysis of additional tumors to increase power. The identification of more driver aberrations and acquired vulnerabilities for each individual tumor will undoubtedly boost personalized care. Developing treatments that target the $\sim 140$ drivers validated so far, however daunting, appears possible; devising one-off therapies for the thousands of aberrations in the long tails will be much more challenging. ${ }^{1,16}$

Four representative cancer types in which precancerous and cancerous lesions have been genetically analyzed. Several important principles can be gleaned from these data. ${ }^{16,40,41}$ First, tumors evolve in three broad phases. In the breakthrough phase, a cell acquires a driver- gene mutation and begins to proliferate abnormally. It takes many cell divisions, and many years, for the cells resulting from this proliferation to be observable clinically, if they ever are. The expansion phase is driven by a second driver-gene mutation enabling the cell to thrive in its local environment despite low concentrations of growth factors, nutrients, oxygen, and appropriate cell-to-cell contacts.

The mutation initiating the breakthrough phase is often very specific, which include a limited number of growth-regulating pathways seem able to initiate neoplasia in a given cell type. As tumors progress, this specificity seems to be progressively lost, so a greater number of driver genes can trans- form a cell from the expansion phase to the invasive phase. It is important to view driver-gene mutations at a pathway level rather than at an individualgene level. ${ }^{16}$ For instance, colorectal cancers are started by the gene mutations in the adenomatous polyposis coli (APC) pathway, which not only consist of APC, but also catenin beta 1 (CTNNB1), SRY-box transcription factor 9 (SOX9), transcription factor 7 like 1 (TCF7L1), transcription factor 7 like 2 (TCF7L2), and APC membrane recruitment protein 1 (AMER1). Similarly, mutations in B-Raf Proto-Oncogene Serine/Threonine Kinase (BRAF) and neuroblastoma Ras viral oncogene homolog (NRAS) that regulate the same pathway, happen in a mutually exclusive manner in melanomas and affect cell growth in a similar way. The order in which driver-gene mutations occur is also important. For example, Ras-pathway mutations are the initiating events for pancreatic ductal adenocarcinomas and melanomas but occur later in colorectal tumorigenesis. If a KRAS gene 
mutation occurred in a normal colonic epithelial cell, a "polyp" might form, but it probably wouldn't progress to a cancer. Indeed, most hyperplastic polyps contain mutations in KRAS but not in APC and are relatively innocuous. In addition, different cancers use different growth-regulating pathways. Some altered pathways are shared by diverse cancer types; for example, mutations in genes regulating the TP53, Ras, and Phosphatidylinositol-4,5-Bisphosphate 3-Kinase Catalytic Subunit Alpha (PIK3CA) pathways drive many types of cancer. In contrast, genes in the APC, BRCA, and $\mathrm{HH}$ (hedgehog) pathways are mutated in fewer cancer types. ${ }^{42}$

The p53 signaling pathway is activated in response to a variety of stress signals, allowing p53 to coordinate transcription programs that ultimately contribute to tumor suppression. Loss of p53 function, through mutations in p53 itself or perturbations in pathways signaling to p53, is a common feature in the majority of human cancers. ${ }^{43}$ Clinical observation and genetic analysis have illuminated cancer pathogenesis to a degree that was unimaginable not long ago, affording unprecedented opportunities for better prevention and treatment. It's a whole new ball game. ${ }^{42}$

\section{Cancer Genetics and Epigenetics}

The past decade has seen a remarkable acceleration in the validation of the concept that cancer is a disease of epigenetic, as well as genetic, abnormalities. Exploration of these connections constitutes one of the most exciting areas in basic cancer biology, with rich potential for clinical translation. ${ }^{18}$ Chromatin is the macromolecular complex of DNA and histone proteins, which provides the scaffold for the packaging of our entire genome. It contains the heritable material of eukaryotic cells. The basic functional unit of chromatin is the nucleosome. It contains 147 base pairs of DNA, which is wrapped around a histone octamer, with two each of histones H2A, H2B, H3, and H4. In general and simple terms, chromatin can be subdivided into two major regions: heterochromatin, which is highly condensed, late to replicate, and primarily contains inactive genes; and euchromatin, which is relatively open and contains most of the active genes.

The term epigenetics was originally coined by Conrad Waddington to describe heritable changes in a cellular phenotype that were independent of alterations in the DNA sequence. Figure 2 shows overall structure of the epigenome in normal human cells. Modifications to DNA and histones are dynamically laid down and removed by chromatinmodifying enzymes in a highly regulated manner. There are now at least four different DNA modifications ${ }^{18,44}$ and 16 classes of histone modifications ${ }^{45,46}$. These modifications can alter chromatin structure by altering noncovalent interactions within and between nucleosomes. They also serve as docking sites for specialized proteins with unique domains that specifically recognize these modifications. These chromatin readers recruit additional chromatin modifiers and remodeling enzymes, which serve as the effectors of the modification. ${ }^{47}$

The information conveyed by epigenetic modifications plays a critical role in the regulation of all DNA-based processes, such as transcription, DNA repair, and replication. Consequently, abnormal expression patterns or genomic alterations in chromatin regulators can have profound results and can lead to the induction and maintenance of various cancers. For instance, malignancies such as follicular lymphoma contain recurrent mutations of the histone methyltransferase mixed-lineage leukemia protein 2 (MLL2) in close to $90 \%$ of cases. ${ }^{48}$ Similarly, UTX, a histone demethylase, is mutated in up to 12 histologically distinct cancers. ${ }^{49}$ Compilation of the epigenetic regulators mutated in cancer highlights histone acetylation and methylation as the most widely affected epigenetic pathways. Much is now known about the importance of promoter cytosine methylation in $\mathrm{CpG}$ islands and gene silencing, and it has been established beyond doubt that such methylation is intimately involved in cancer development. ${ }^{20}$ Most $\mathrm{CpG}$ islands are found in the proximal promoter regions of almost half of the genes in the mammalian genome and are, generally, unmethylated in normal cells. In cancer, however, the hypermethylation of these promoter regions is now the most well-categorized epigenetic change to occur in tumors; it is found in virtually every type of human neoplasm and is associated with the inappropriate transcriptional silencing of genes. ${ }^{50,51}$

Additionally, there is a growing list of candidate tumor-suppressor genes that are silenced by promoter hypermethylation in certain cancers. These genes are predicted to be important for tumorigenesis on the basis of their presumed function, but seem not to be frequently mutated in such cancers. Examples of these genes include O6-methylguanine-DNA methyl-transferase (MGMT) ${ }^{52}$, which encodes an important DNA-repair gene; cyclindependent kinase inhibitor 2B (CDKN2B), which encodes $\mathrm{p} 15$, a cell-cycle regulator ${ }^{53}$, and Ras association domain 


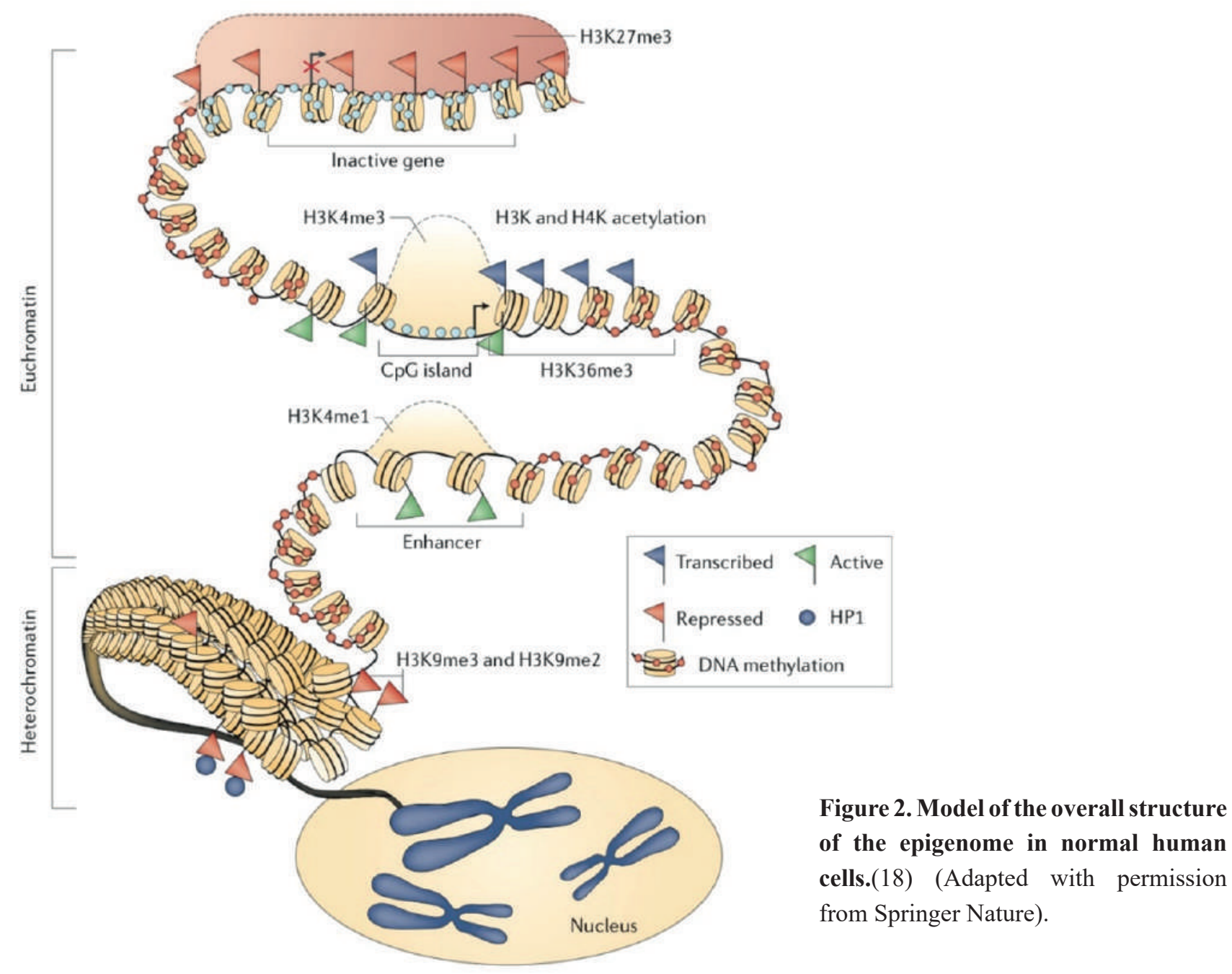

family 1 isoform A (RASSF1A $)^{54,55}$, which encodes a protein of unknown function that can bind to the Ras oncogene. Promoter hypermethylation is the only mechanism for the loss of function of many of these genes in tumors. ${ }^{56}$ The cancer epigenome and relevant gene mutations are shown in Figure 3, while Table 1 showed the altered expression of some epigenetic modifying genes in cancer.

Three active DNA methyltransferases (DNMTs) have been identified in higher eukaryotes. DNMT1 is a maintenance methyl-transferase that recognizes hemimethylated DNA generated during DNA replication and then methylates newly synthesized $\mathrm{CpG}$ dinucleotides, whose partners on the parental strand are already methylated. ${ }^{57}$ Conversely, DNMT3a and DNMT3b, although also capable of methylating hemimethylated DNA, function primarily as de novo methyltransferases to establish DNA methylation during embryogenesis. ${ }^{58}$ DNA methylation provides a platform for several methyl-binding proteins. These include MBD1, MBD2, MBD3, and MeCP2. These in turn function to recruit histone-modifying enzymes to coordinate the chromatin-templated processes. ${ }^{59}$

The ten-eleven translocation (TET 1-3) family of proteins have now been demonstrated to be the mammalian DNA hydroxylases responsible for catalytically converting $5 \mathrm{mC}$ to $5 \mathrm{hmC}$. Indeed, iterative oxidation of $5 \mathrm{hmC}$ by the TET family results in further oxidation derivatives, including 5-formylcytosine (5fC) and 5-carboxylcytosine (5caC). Interestingly, TET2-deficient mice develop a chronic myelomonocytic leukemia (CMML) phenotype, which is in keeping with the high prevalence of TET2 mutations in patients with this disease. ${ }^{60,61}$ The clinical implications of TET2 mutations have largely been inconclusive; however, in some subsets of AML patients, TET2 mutations appear to confer a poor prognosis. ${ }^{62}$ 


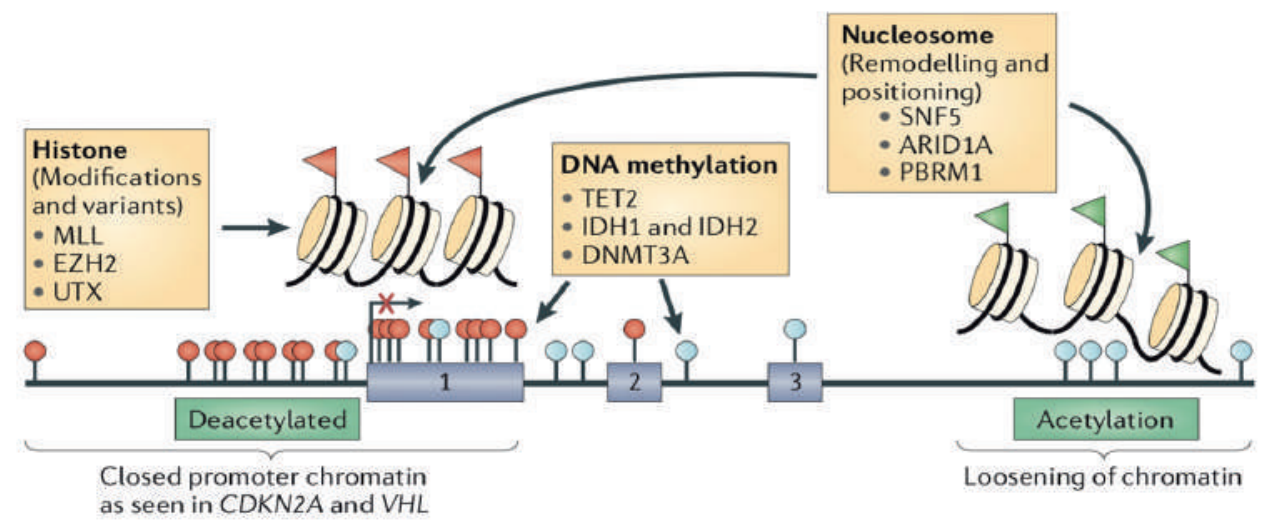

Figure 3. The cancer epigenome and relevant gene mutations.(18) MLL: mixed lineage leukaemia; EZH2: enhancer of zeste homolog 2; UTX: ubiquitously transcribed tetratricopeptide repeat, X chromosome; TET2: Tet methylcytosine dioxygenase 2; IDH: isocitrate dehydrogenase; DNMT3A: DNA (cytosine-5)-methyltransferase 3A; SNF5: Ini1/Baf47/ Smarcb1; ARID1A: AT-rich interactive domain-containing protein 1A; PBRM1: Polybromo 1. (Adapted with permission from Springer Nature).

Acetylation is highly dynamic and is regulated by the competing activities of two enzymatic families, the histone lysine acetyltransferases (KATs) and the histone deacetylases (HDACs). There are two major classes of KATs: type-B, which are predominantly cytoplasmic and modify free histones, and type-A, which are primarily nuclear. ${ }^{47}$ In the context of malignancy, chimeric fusion proteins that are seen in leukemia, such as promyelocytic leukemia/retinoic acid receptor alpha (PML-RAR $\alpha$ ), promyelocytic leukemia zinc finger/retinoic acid receptor

Table 1. Altered expression of some epigenetic modifying genes in cancer.

(66) (Adapted with permission from Springer Nature).

\begin{tabular}{|c|c|c|}
\hline Gene & Change & Cancer \\
\hline IGF2 & Increased & LOI in colorectal, gastric and breast cancers \\
\hline Class IHDACs & Increased & $\begin{array}{l}\text { Gastrointestinal, prostate, breast and } \\
\text { cervical cancers }\end{array}$ \\
\hline $\mathrm{EZH} 2$ & Increased & Prostate cancer \\
\hline $\mathrm{EZH} 2$ & Increased & Breast cancer \\
\hline HDACs & Increased & Several \\
\hline HATs & Decreased & Several \\
\hline HDACs & Increased & Colon cancer \\
\hline HDAC6 & Increased & Breast cancer \\
\hline SIRT1 & Increased & Prostate cancer \\
\hline SIRT3 & Increased & Breast cancer \\
\hline KDM5C & Increased & Breast cancer \\
\hline SMYD3 & Increased & Liver, colon and breast cancers \\
\hline EHMT1 & Decreased & Medulloblastoma \\
\hline DNMT1 & Increased & Pancreas, liver, bladder and breast cancers \\
\hline DNMT3B & Increased & Breast cancer \\
\hline AID & Increased & Leukaemia \\
\hline
\end{tabular}


alpha (PLZF-RAR $\alpha$ ), and acute myeloid leukemia 1/ EightTwenty One oncoprotein (AML1-ETO), have been shown to recruit HDACs to mediate aberrant gene silencing, which contributes to leukemogenesis. ${ }^{63}$ HDACs can also interact with nonchimeric oncogenes such as BCL6, whose repressive activity is controlled by dynamic acetylation. ${ }^{64}$ Importantly, inhibitors of histone deacetylases (HDAC-I) are able to reverse some of the aberrant gene repression seen in these malignancies and induce growth arrest, differentiation, and apoptosis in the malignant cells. ${ }^{63,65}$

Several DNA repair genes are known to be subject to promoter methylation. MGMT removes carcinogen-induced O6-methyl-guanine adducts from DNA, which result in G to A transition mutations. Cancers with hypermethylated MGMT are susceptible to genetic mutation in critical genes such as p53 or KRAS. ${ }^{18,66,67}$ The mismatch-repair gene MutL homolog 1 (MLH1) plays an important role in genomic stability, and the loss of function of this gene by promoter hypermethylation causes microsatellite instability, which is a key factor in several cancers, including colorectal and endometrial cancers. ${ }^{68}$ The MLH1 promoter is already hypermethylated in normal colonic epithelium of some colorectal cancer patients, suggesting this epigenetic change is an early event of tumorigenesis and precedes downstream genetic mutation. ${ }^{69}$

DNMT1 mutations have been described in colorectal cancer $^{70}$, and as previously noted, DNMT3A mutations are frequent in myelodysplastic syndromes (MDS) and acute myeloid leukemia (AML) $)^{71-73}$. Germline mutations in DNMT3B underlie immunodeficiency-centromeric instability-facial anomalies (ICF) syndrome and chromosome instability $^{74}$, and SNPs in DNMT3B have been suggested to be associated with risk of several cancers including breast and lung adenocarcinoma ${ }^{75}$. Other mutations of DNMT3A occur at several positions and generally represent a loss of function, similar to DNMT3B mutations that are associated with ICF syndrome. ${ }^{71}$

Epigenetic alterations are leading candidates for the development of specific markers for cancer detection, diagnosis and prognosis. The enzymatic processes that control the epigenome present new opportunities for deriving therapeutic strategies designed to reverse transcriptional abnormalities that are inherent to the cancer epigenome. ${ }^{18}$ DNA methylation biomarkers can be used for the molecular prognosis of potentially curable, stage I non-small-cell lung cancer (NSCLC). The concurrent hypermethylation of four genes, CDKN2A and CDH13 in particular, in primary tumor and mediastinal lymph node biopsy samples, strongly correlates with early recurrence and death. ${ }^{76}$

Although at the genetic level cancer is caused by diverse mutations, epigenetic modifications are characteristic of all cancers, from apparently normal precursor tissue to advanced metastatic disease, and these epigenetic modifications drive tumor cell heterogeneity. ${ }^{66}$ Rather than separating genetics from epigenetics, or trying to decide which is more important for cancer initiation and progression, the past few years have emphasized that these fields are merging. This is leading to an understanding of how mutations and epigenetic alterations work together to cause this disease. ${ }^{18}$

\section{Oncogenic Signaling Pathways}

Cancer arises through the sequential accumulation of mutations in oncogenes and tumor suppressor genes. ${ }^{77}$ Typical solid tumors each contain hundreds or thousands of genetic alterations, the vast majority of which are point mutations or small insertions or deletions. Only a few of these are drivers, conferring selective growth advantages to the cancer cell in which they occur. ${ }^{16,78,79}$ The remaining thousands of mutations are passengers that coincidentally occurred during the large number of cell divisions associated with the neoplastic process. ${ }^{80}$ Driver genes are defined as genes containing driver mutations. Although genes can be confidently identified as drivers because mutations in them are observed in many tumors, the identification of driver genes that are infrequently mutated is more difficult. Several criteria for identifying driver mutations have been proposed $^{16,78,79}$, but none has been validated in an objective fashion. In addition to point mutations, alterations such as gene fusions, chromosomal translocations, and copy number changes further complicate our understanding of tumors' genomic landscapes. ${ }^{81}$

One of the major goals of cancer genomics is the identification of the driver genes responsible for tumor initiation and progressionIn chronic myeloid leukemia, a single mutation (a chromosome translocation juxtaposing the $\mathrm{BCR}$ and $\mathrm{ABL}$ genes) may be all that is required to convert a normal bone marrow stem cell into a tumor cell ${ }^{82}$, and the transformation of myelodysplastic syndrome to acute myeloid leukemia appears to be the result of a single event $^{83}$. For most solid tumors, however, it is generally thought that a larger number of driver gene mutations is required. 
Genetic alterations in signaling pathways that control cell-cycle progression, apoptosis, and cell growth are common hallmarks of cancer, but the extent, mechanisms, and co-occurrence of alterations in these pathways differ between individual tumors and tumor types. TCGA analyzed the mechanisms and patterns of somatic alterations in ten canonical pathways: cell cycle, Hippo, Myc, Notch, Nrf2, PI-3-Kinase/Akt, RTK-RAS, TGFb signaling, p53 and $\mathrm{b}$-catenin/Wnt. The detailed landscape of pathway alterations in 33 cancer types, stratified into 64 subtypes, and identified patterns of co-occurrence and mutual exclusivity. Eightynine percent of tumors had at least one driver alteration in these pathways, and $57 \%$ percent of tumors had at least one alteration potentially targetable by currently available drugs. Thirty percent of tumors had multiple targetable alterations, indicating opportunities for combination therapy. ${ }^{84}$ The pathways analyzed are cell cycle, Hippo signaling, Myc signaling, Notch signaling, oxidative stress response/Nrf2, PI-3-Kinase signaling, receptor-tyrosine kinase (RTK)/ RAS/MAP-Kinase signaling, TGF- $\beta$ signaling, p53 and $\beta$-catenin/Wnt signaling.

Upon mapping these significant pairs to the affected pathways, numerous mutually exclusive pairs was found within the p53, cell-cycle, Ras, and PI3K pathways, suggesting that one alteration is sufficient to functionally alter each of these pathways or that more than one might be disadvantageous. On the other hand, the Hippo, RTK, and, to a lesser extent, Wnt pathways often had multiple alterations per tumor sample, suggesting co-occurring events that mediate synergistic activation of each pathways. ${ }^{84}$

Oncogene activation disturbs cellular processes and accommodates a complex landscape of changes in the genome that contribute to genomic instability, which accelerates mutation rates and promotes tumorigenesis. Part of this cellular turmoil involves deregulation of physiologic DNA replication, widely described as replication stress. Oncogene-induced replication stress is an early driver of genomic instability and is attributed to a plethora of factors, most notably aberrant origin firing, replication-transcription collisions, reactive oxygen species, and defective nucleotide metabolism. $^{34}$

The seven known human oncogenic viruses are Epstein-Barr virus (EBV), hepatitis B virus (HBV), human T-lymphotropic virus 1 (HTLV-1), human papillomaviruses (HPVs), hepatitis C virus (HCV), Kaposi sarcoma-associated herpesvirus (KSHV) and Merkel cell polyomavirus (MCPyV) ${ }^{85,86}$ Oncogene-induced RS has long been recognized as an early driver of cancer, and investigating the mechanics of this process has been established as a field in its own right. Understanding RS has accelerated cancer diagnosis and assisted the development of more sophisticated anticancer treatments. ${ }^{34}$

\section{DNA Repair Genes}

DNA repair activities are a number of processes that allow the cell to identify and then correct damage to DNA molecules. It is the current consensus that in a somatic cell several hundred thousand DNA repair processes are performed per day. ${ }^{87}$ First, we should distinguish damage from mutation. Damage is a physical problem: lack of a base or a break in a strand. A mutation is a modification of several bases in a strand. DNA repair mechanisms are not able to recognize mutations and so repair is not possible.

Oxidation of bases is probably the most important source. This damage may be of environmental origin such as UV-A and $\mathrm{B}$, ionizing radiations, or of endogenous origin. The oxidases xanthine, glycolate, amine, membrane nicotinamide adenine dinucleotide phosphate (NADPH) oxidases and mitochondrial metabolic activity (OXPHOS) generate reactive oxygen species (ROS). The most common damage observed in DNA oxidation is the formation of 8-oxo-deoxyguanosine (8-OHdG), however other oxidation products may also be detected. Peroxidation of membrane polyunsaturated fatty acid leads to malondialdehyde (MDA), 4-hydroxynonenal (4-HNE) and 2,3-epoxy-4- HNE degradation products which form MDA guanine, 4-HNE

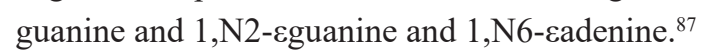

Two major types of DNA repair exist. The first one repairs DNA damage that arises from external sources such as UV light or ionizing rays and from endogenous DNA damage, for example, due to oxidative stress. To this type of repair belong the base excision repair (BER) pathway, the direct reversal of DNA damage, and the nucleotide excision repair (NER) pathways. The other general mechanism of repair deals with the mistakes made during DNA replication. This system includes factors involved in MMR, homologous recombination, certain DNA helicases, editing and processing nucleases, and other genes, which are defective in diseases associated with sensitivity to DNA damaging agents. ${ }^{88-90}$

In BER, generally a single damaged DNA base is removed by a DNA glycosylase-type enzyme. The resulting 
abasic site is then repaired by additional steps including DNA backbone incision, gap filling, and ligation. The most common mutation found in human genetic diseases and cancer is the $\mathrm{C}$ to $\mathrm{T}$ transition mutation found at $\mathrm{CpG}$ dinucleotides. These mutations are thought to arise from deamination of 5 -methylcytosine. ${ }^{91}$ The methyl-CpG binding domain protein 4 (MBD4) has the ability to bind methylated $\mathrm{DNA}^{92}$, and furthermore, it preferentially binds to the T:G mismatches at $\mathrm{CpG}$ sites $^{93}$. MBD4 and TDG, promoter methylation has been found in different cancer types. Several multiple myeloma cell lines (KAS-6/1, KMS-11, OPM2, KMS-12, and JIM3) showed promoter methylation and decreased gene expression compared with normal plasma cells for TDG. ${ }^{4}$ MBD4 is significantly methylated in CRC cell lines and ovarian cancer (OC) cell lines. ${ }^{95}$ In sporadic CRC, promoter methylation of MBD4 is an early event in tumorigenesis and could be used as a prognostic factor.

Another BER gene for which promoter methylation has been found is 8-Oxoguanine glycosylase (OGG1). OGG1 repairs oxidatively damaged guanine bases in DNA and mutations of this gene may be involved in tumorigenesis. ${ }^{96-98}$ But at this point, a methylated promoter of OGG1 is only known in 5\% of thyroid cancer and in some thyroid cancer cell lines. ${ }^{99}$ MGMT encodes the O6methylguanine-DNA methyltransferase. ${ }^{100,101}$ This enzyme repairs DNA alkylation damage. Alkylation reactions lead to formation of a methyl group ( $\left.\mathrm{CH}^{-}\right)$at the $\mathrm{O} 6$ position of guanine. O6-methylguanine pairs with thymine rather than cytosine and promotes $\mathrm{G}: \mathrm{C}$ to A:T mutations. MGMT repairs this damage and protects the DNA by transferring the methyl group to a cysteine residue in the protein. Epigenetic inactivation by promoter methylation of the MGMT gene is very well established. This gene is epigenetically silenced in a variety of cancers. ${ }^{102}$ Specifically, MGMT methylation is found in glioblastomas ${ }^{52,103,104}$, colon cancer $^{105,106}$, NSCLC $^{107,108}$, gastric carcinoma ${ }^{109}$, head and neck squamous cell carcinoma (HNSCC) $)^{110-112}$, and many other cancer types.

The NER system consists of two sub-pathways. The global genome repair (GGR) mechanism repairs DNA damage in transcriptionally inactive parts of the genome. ${ }^{113,114}$ The second NER component is responsible for repair of transcribed DNA and is referred to as transcriptioncoupled repair (TCR). ${ }^{15,116}$ These two NER function differ in the damage recognition step. In addition, it is known that two other genes, which are part of the NER system, are methylated in human tumors. ${ }^{117}$ The genes RAD23A and
ERCC1, which are involved in DNA damage recognition and incision, respectively, are also inactivated through promoter methylation. The RAD23A gene is methylated in the multiple myeloma cell line KAS 6/1 ${ }^{118}$ and ERCC1 is methylation-silenced in glioma cell lines and glioma tumors ${ }^{119}$.

The DNA MMR protein MLH1 is encoded by the MLH1 gene in humans and is a homologue of the DNA MMR gene mutL of Escherichia coli. The MMR function is associated with DNA replication, to correct for deficiencies in DNA polymerase proofreading function. A missing gene or mutations of this gene and other MMR genes (MSH2, MSH6, or PMS2) leads to microsatellite instability (MSI) and this dysfunction is highly associated with hereditary non-polyposis colon cancer. ${ }^{119}$ Constitutional methylation of the MLH1 gene, characterized by soma-wide methylation of a single allele and transcriptional silencing, has been identified in a subset of Lynch syndrome (LS) cases lacking a sequence mutation in MLH1. ${ }^{120-122}$ This particular example provides strong support for the proposal that methylation of a DNA repair gene can be a crucial mechanism in carcinogenesis.

If it is not possible to repair the DNA damage before replication, the DNA may be repaired by homologous pairing. Because of DNA polymerase-blocking damage, DNA strand breaks will be generated, which can be repaired by the homologous recombination repair system. The BRCA1 and BRCA2 proteins are involved in this repair pathway. The BRCA1 and BRCA2 genes are tumor suppressor genes and the proteins, together with RAD51, form a complex to repair DNA strand breaks. ${ }^{123,124} \mathrm{~A}$ few years after their initial discovery, researchers found promoter methylation for BRCA1 which correlated with low mRNA levels. ${ }^{125}$ For BRCA2, it has been found that a low mRNA level is generally not caused by hyper-methylation of the promoter. ${ }^{126,127}$ BRCA1 is most often methylated in breast and OC but also in gastric cancer ${ }^{128}$, NSCLC ${ }^{129}$, uterine cancer ${ }^{130}$, and bladder cancer ${ }^{131}$.

The gene product of X-ray repair cross complementing (XRCC) 5 is the protein $\mathrm{K} 80 .{ }^{132}$ Together with the gene product of XRCC6, it forms the 80 and $70 \mathrm{kDa}$ subunits of the $\mathrm{K} 70 / \mathrm{K} 80$ heterodimer protein $\mathrm{Ku}$, which is involved in the binding of double-strand breaks (DSBs) during nonhomologous end-joining. ${ }^{133,134}$ Together with the DNAdependent protein kinase catalytic subunit DNA-PKcs), the $\mathrm{Ku}$ heterodimer forms the full complex DNA-PK. ${ }^{135}$ The product of the ATM gene is a serine protein kinase and 
tumor suppressor. When a DNA DSB has been generated, cell cycle arrest is initiated by the ATM signaling network. After an initial finding that CRC cell lines are methylated at the ATM gene ${ }^{136}$, it has been found that also primary breast tumors are very often methylated $(78 \%)^{137}$. But these high methylation frequencies do not seem to be a general finding in breast cancer. Fanconi anemia is an autosomal recessive genetic disorder. Thirteen genes are associated with this disease. These genes are DNA repair genes and mutation of each of them leads to the same disorder. The genes are called Fanconi anemia, complementation group A, B, C, D1, D2, E, F, G, I, J, L, M, and N (FANCA-N). Assembly of a complex of FANC proteins is activated by replicative stress, particularly DNA damage caused by cross-linking agents.

The last interesting candidate is the CHK2 checkpoint homologue. CHK2 is a protein kinase functioning in an important DNA damage response pathway and is involved in regulation of cell cycle arrest. ${ }^{138}$ It has been shown that this gene is inactivated by promoter methylation in NSCLC with $28.1 \%$ tumor methylation frequency in total (squamous cell lung carcinoma 40\%; adenocarcinoma 19\%) and in NSCLC cell lines. ${ }^{139,140}$ In gliomas, CHK2 is methylated in the proximal $\mathrm{CpG}$ island promoter and is significantly downregulated. ${ }^{141}$ Epigenetic inactivation of DNA repair genes in cancer has been reported for several DNA repair pathways including BER, NER, DNA MMR, and several other DNA damage processing mechanisms. Within one DNA repair pathway, specific genes are often preferentially methylated. It remains to be determined whether this specificity is due to selection of particular repair gene silencing events in promoting tumorigenesis or is due to preferential targeting of the DNA methylation machinery to specific DNA repair gene promoters. ${ }^{90}$

\section{Tumor Suppressor Genes}

Many genetic studies in different cancers have identified a small number of genes that must be mutated or altered to promote the growth of malignant cells. ${ }^{142}$ The two main properties of cancer cells, uncontrolled cell growth and the ability to invade other tissues, are the result of these genetic and epigenetic alternations. Genetic alternations include genetic mutations, genomic instability, loss of heterozygosity (LOH), and gene copy number variation (CNV). By contrast, epigenetic changes include histone modifications, DNA methylation, and loss of imprinting
(LOI). These modifications regulate gene expression without altering the underlying nucleotide sequence. ${ }^{143-145}$

In general, cancer-related genes can be divided into two broad classes, protooncogenes and tumor suppressor genes (TSGs). Proto-oncogenes are generally involved in pathways that promote cellular growth. These genes can cause normal cells to become cancerous when they are activated by mutations or alterations. Mutations in protooncogenes are typically dominant in nature, and the mutated versions of these genes are known as oncogenes. ${ }^{146}$ TSGs is considered as another kind of crucial genes, which are involved in DNA damage repair, inhibition of cell division, induction of apoptosis, and suppression of metastasis. Therefore, loss of TSGs function would result in the onset and progression of cancer. ${ }^{147}$

Cancer is a disease caused by the accumulation of genetic and epigenetic changes in two types of genes: tumor suppressor genes (TSGs) and protooncogenes. Extensive research has been conducted over the last few decades to elucidate the role of TSGs in cancer development. In cancer, loss of TSG function occurs via the deletion or inactivation of two alleles, according to Knudson's two-hit model hypothesis. It has become clear that mutations in TSGs are recessive at the level of an individual cell; therefore, a single mutation in a TSG is not sufficient to cause carcinogenesis. However, many studies have identified candidate TSGs that do not conform with this standard definition, including genes inactivated by epigenetic silencing rather than by deletion. ${ }^{148}$

Several oncogenic driver mutations have been identified and are usually mutually exclusive with one another. However, a greater number of genetic aberrations have been identified ( $\sim 50-100$ per tumor) that appear to cause loss of function. These aberrations need to be validated as functionally important tumor-suppressor genes (TSGs) and for their impact in the context of other mutations. Genetically engineered mouse models (GEMMs) have been critical for uncovering fundamental aspects of lung cancer biology; however, elucidation of oncogene and tumor-suppressor biology in GEMMs is time-consuming and expensive, requiring germline alterations and subsequent breeding to obtain the desired genotypes. Recently, CRISPR-Cas9 technology has been used to accelerate this process. ${ }^{149,150}$ Lentiviruses encoding Cre recombinase, Cas9 nuclease and sgRNA are delivered by intratracheal instillation into the lungs of mice to initiate lung adenocarcinomas with, for example, expression of mutant KRASG12D alone or in 
combination with Trp53 loss. Cas9 induces indels in genes targeted by the sgRNAs, producing out-of-frame mutant transcripts of these genes that are degraded. ${ }^{151}$

A study employed sgRNAs against 11 genes with established tumor- suppressor provenance in the context of mouse lung adenocarcinomas with mutant KrasG12D. ${ }^{152}$ Indels in 6 of the 11 genes led to increased tumor growth, with Setd 2 and Lkb1 loss having the greatest effect. They also determined which combinations of the 11 TSGs gave larger tumors. Two main comparisons were of mice with wild-type Trp53 versus Trp53-null mice and of mice with wild-type Lkb1 versus Lkb1-null mice; the effect on tumor size from disruption of the paired TSGs varied dramatically depending on the Trp53 versus Lkb1 TSG background. ${ }^{151}$ The TP53 is inactivated in the majority of cancers. ${ }^{153,154}$ It negatively regulates the cell cycle and is involved in genomic stabilization and angiogenesis. ${ }^{153,154}$ Inactivation of TP53 by homozygous deletion (HD), LOH, point mutations, and/or methylation has been frequently reported in human cancers. In addition to these genetic inactivation mechanisms, the cellular p53 level is also regulated through ubiquitination-mediated degradation. ${ }^{155} \mathrm{~A}$ number of RING finger domain-containing E3 ligases, including MDM2, MDM4, herpesvirus-associated ubiquitin-specific protease (HAUSP), constitutively photomorphogenic 1 (COP1), Pirh2, and ARF-BP1, can ubiquitinate p53. ${ }^{156-160}$

Many reports demonstrate that the "two-hit" model, in which a genetic and an epigenetic event lead to loss of TSG expression, does not fully explain the inactivation of TSGs in human cancers. Therefore, we propose a revised "multiple-hit" model for the inactivation of TSGs, which includes a non-genetic/epigenetic event such as transcriptional regulation, proteasome degradation, or abnormal nucleocytoplasmic shuttling (Figure 4). This revised "multiple-hit" model incorporates the inactivation of TSGs at the molecular level and could suggest novel targets for anti-cancer therapy. ${ }^{148}$

\section{Lnych Syndrome (LS)}

LS is the hereditary disorder that most frequently predisposes to colorectal cancer (CRC). An estimated one of every 35 cases of CRC is attributable to $\mathrm{LS}^{161}$ and certain extracolonic cancers are also integral to the syndrome; endometrial cancer is the most predominant of these. It is estimated that one million individuals in the United States carry LS mutations, with only $5 \%$ of these being aware of their cancer predisposition. ${ }^{162}$ LS is an autosomal dominant disorder with colorectal malignancy as the major clinical consequence. ${ }^{163-167}$ The lifetime risk of CRC in LS has been variably estimated and appears dependent on sex and the MMR gene mutated. ${ }^{168,170}$ Most reports of lifetime risks of CRC for MLH1 and MSH2 gene mutation carriers range from $30 \%$ to $74 \%$. Lower cumulative lifetime risk for colorectal malignancy ranging from $10 \%$ to $22 \%$ has been found in patients with MSH6 mutations ${ }^{24}$ and $15 \% 20 \%$ in those with PMS2 mutations. ${ }^{171}$ Mean age at CRC diagnosis in LS patients is $44-61$ years ${ }^{172,173}$ compared with 69 years in sporadic cases of CRC. ${ }^{174}$ In LS, colorectal tumors arise primarily $(60 \%-80 \%)$ on the right side of the colon (proximal to the splenic flexure) compared with $30 \%$ in sporadic CRC. ${ }^{175}$ A high rate of metachronous CRC (16\% at 10 years; $41 \%$ at 20 years) is noted in LS patients with segmental surgical resection of the initial CRC. ${ }^{176-178}$

Population carrier frequency of pathogenic MMR mutations was estimated to be 1/714 for PMS2, 1/758 for MSH6, 1/1,946 for MLH1, and 1/2,841 for MSH2. ${ }^{179}$ These authors calculated that these figures would lead to a population estimate of $1 / 279$ for any MMR gene. It has usually been reported that an estimated $80-90 \%$ of LS involves mutations in MLH1 or MSH2, while mutations in MSH6 or PMS2 account for $10-20 \% .{ }^{180} \mathrm{Up}$ to $3 \%$ of LS is caused by an epithelial cell adhesion molecule (EPCAM) mutation. However, these frequencies have been reported in patients ascertained via fulfillment of the Amsterdam or Bethesda clinical criteria for a presentation of CRC or endometrial cancer, which may have been biased against the identification of MSH6 and PMS2 mutations. ${ }^{181,182}$

Hereditary nonpolyposis colorectal cancer (HNPCC) was historically synonymous with LS, but it is now possible to differentiate among familial nonpolyposis CRC syndromes on the basis of a mutated gene. ${ }^{183}$ Differentiation of HNPCC disorders can be aided by molecular analysis of tumors and germline mutation testing, and has implications for their diagnosis and management. ${ }^{184}$ Conditions associated with defective DNA MMR include LS (germline MMR mutation), constitutional MMR deficiency syndrome (biallelic germline MMR mutations) ${ }^{185}$, Lynch-like syndrome (some cases caused by biallelic somatic MMR mutations, some due to unknown causes) ${ }^{38}$, and sporadic CRC with MSI (somatic biallelic methylation of MLH1) ${ }^{186}$. Significant inter-patient heterogeneity exists among patients with LS and this poses challenges for diagnosis and clinical management. Some of this heterogeneity may be attributed 


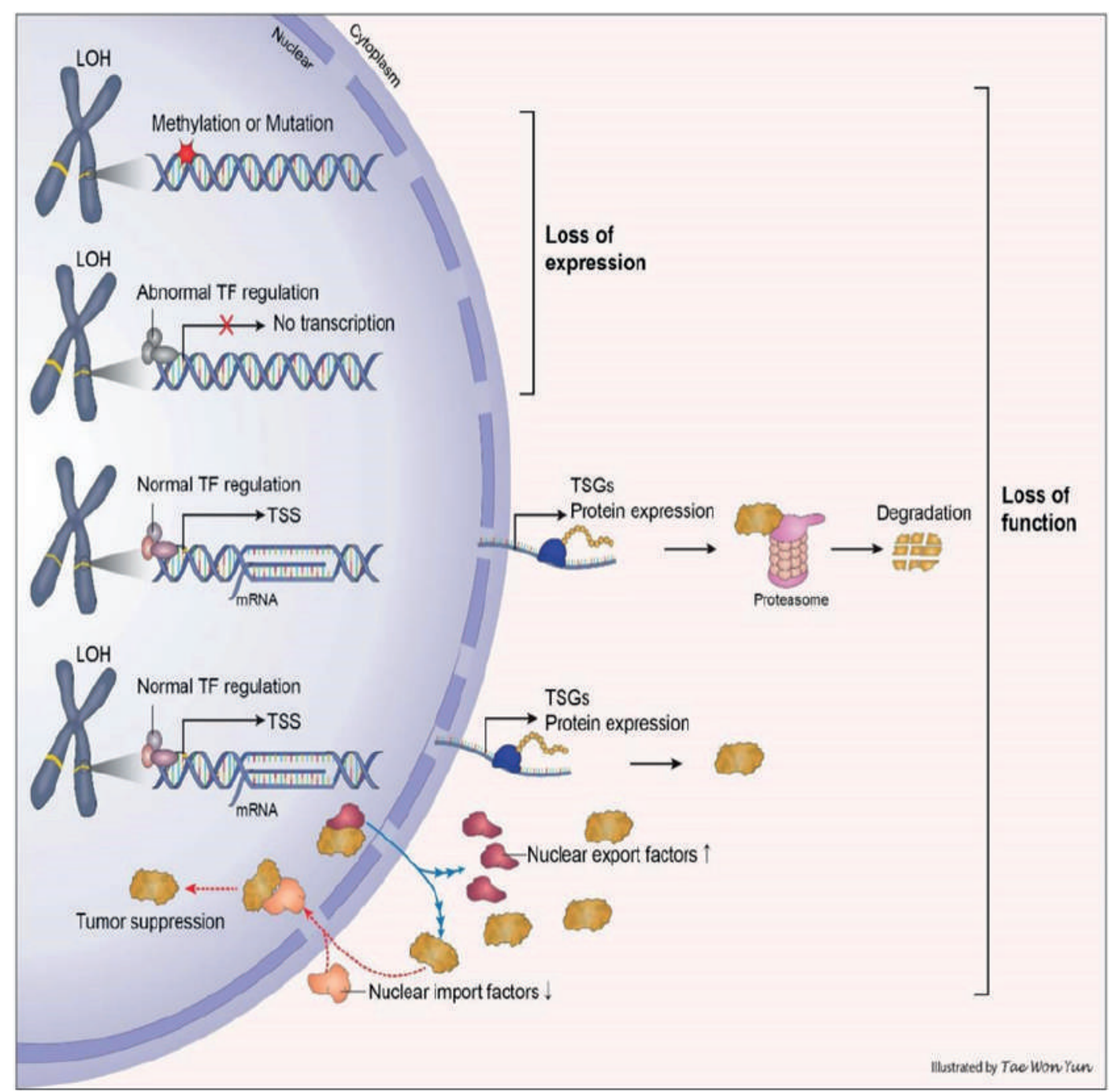

Figure 4. A brief summary of multiple hit model for the loss of tumor suppressor gene function in human cancer.(148) (Adapted with permission from Karger AG).

to which of the MMR genes is mutated. Life- time risk of CRC for MLH1 or MSH2 mutation carriers is estimated to be $52-85 \%$, while that for MSH6 mutation carriers is $10-22 \%$ and that for PMS2 mutation carriers is $15-20 \%$. Lifetime risk of endometrial cancer for MLH1 or MSH2 mutation carriers is $25-60 \%$, while this risk is $16-26 \%$ for MSH6 and $15 \%$ for PMS2. ${ }^{187}$ For patients with an EPCAM deletion, the lifetime risk for CRC is equivalent to patients with an MSH2 mutation, but the lifetime risks for extracolonic cancers is lower ( $\sim 12 \%$ for endometrial cancer), unless the deletion extends into MSH2. ${ }^{188,189}$

In addition to CRC, LS patients have a significantly increased risk for a wide variety of extracolonic malignancies (Table 2). ${ }^{190}$ The highest risk is for endometrial cancer (EC), which occurs in up to $54 \%$ of women with MLH1 and
MSH2 mutations, with lower risk in those with PMS2 (15\%) mutations ${ }^{171}$ and much higher risk in persons with MSH6 mutations (71\%). ${ }^{170} \mathrm{LS}$ caused by MSH6 mutation is also characterized by later onset of colorectal and endometrial cancers than with other MMR gene alternations. Increased lifetime risk of transitional cell carcinoma of the ureter, renal pelvis, and bladder; adenocarcinomas of the ovary, stomach, hepatobiliary tract, and small bowel; brain cancer (glioblastoma); and cutaneous sebaceous neoplasms also occur in LS families. ${ }^{168,173,191} \mathrm{An}$ increased risk of pancreas cancer in LS has been described by some investigators, but not others. ${ }^{192-196}$ The relationship between LS and breast cancer is unclear. Although a small increase in absolute risk of breast cancer $(18 \%)$ has been found ${ }^{197}$, most registry reports have not demonstrated this consistently. ${ }^{198}$ 
Table 2. Cumulative risks of extracolorectal cancer by age 70 years in lynch syndrome.(190) (Adapted with permission from Americn Doctor Society for Gastrointestinal Endoscopy).

\begin{tabular}{lccc}
\hline Cancer & $\begin{array}{c}\text { Risk general } \\
\text { population, } \%\end{array}$ & Risk in LS, \% & $\begin{array}{c}\text { Mean age at } \\
\text { diagnosis, } \mathbf{~}\end{array}$ \\
\hline Endometrium & 2.7 & $14-54$ & 65 \\
\hline MLH1/MSH2 & & $17-71$ & $48-62$ \\
\hline MSH6 & $<1$ & 15 & $54-57$ \\
\hline PMS2 & 1.6 & $0.2-13$ & 49 \\
\hline Stomach & $<1$ & $4-20$ & $49-55$ \\
\hline Ovary & $<1$ & $0.02-4$ & $43-45$ \\
\hline Hepatobiliary tract & $<1$ & $0.2-25$ & $54-57$ \\
\hline Urinary tract & $<1$ & $0.4-12$ & $52-60$ \\
\hline Small bowel & $<1$ & $1-4$ & $46-49$ \\
\hline Brain/central nervous system & 1.5 & $1-9$ & 50 \\
\hline Sebaceous neoplasm & 16.2 & $0.4-4.0$ & NA \\
\hline Pancreas & 12.4 & $9-30$ & $63-65$ \\
\hline Prostate & & $5-18$ & $59-60$ \\
\hline Breast & & & 52 \\
\hline
\end{tabular}

NA. Not available.

However, there are early-onset breast cancers in some LS kindreds in which tumors have the microsatellite instability (MSI) phenotype. ${ }^{199,200}$ In several studies, the relative risk of prostate cancer is 2.0- to 2.5 -fold higher than the general population risk. ${ }^{201}$ Also, an excess of laryngeal and hematologic malignancies has been described, but a definite association to LS has not been established. ${ }^{175,202,203}$ An association between sarcoma and LS probably exists, but the magnitude of risk is unclear. ${ }^{204}$

A recent study presented data that led them to suggest that some MSH6 and PMS2 mutation carriers may present with a hereditary breast-ovarian cancer (HBOC)-like phenotype and are more likely to be missed by current LS screening and testing, which tends to concentrate on occurrences of CRC and endometrial cancer. The researcher reviewed the clinical histories of patients who had undergone multigene panel testing for a diagnosis of CRC and/or endometrial cancer, and/or breast cancer, and/or ovarian cancer. ${ }^{181}$ Of their 528 MMR mutation carriers identified,
$22.2 \%$ met BRCA1 and BRCA2 (BRCA1/2) testing criteria but not LS criteria while 5.1\% met neither BRCA1/2 nor LS testing criteria. MSH6 and PMS2 mutations were more frequent than MLH1 and MSH2 mutations among patients who met BRCA1/2 testing criteria but did not meet LS testing criteria $\left(\mathrm{P}=4.3 \times 10^{-7}\right)$. It was noted that $11.9 \%$ of the 528 MMR mutation carriers had breast cancer only ${ }^{63}$, while $27.3 \%$ had CRC only ${ }^{144}$, and $27.5 \%$ presented with breast or ovarian cancer as their first primary cancer ${ }^{205}$.

HNPCC designates patients and/or families who fulfill the Amsterdam I or II criteria. LS is applied to patients and families in which the genetic basis can be linked to a germline mutation in one of the DNA MMR genes or the EPCAM gene. Lynch-like syndrome describes patients and/or families in which molecular testing demonstrates the presence of MSI and/or abnormalities in the expression of MMR gene proteins on IHC testing of tumor tissue expression, but no pathogenic germline mutation can be found in the patient (e.g., in the absence of a BRAF mutation 
and/or MLH1 promoter hypermethylation when there is loss of tumor expression of the MLH1 protein). ${ }^{206}$

LS is caused by inactivation of one of several DNA MMR genes. These genes function to maintain fidelity of the DNA during replication by correction of nucleotide base mispairs and small insertions or deletions generated by miincorporations or slippage of DNA polymerase during DNA replication. Germline mutation in the MMR genes MLH1, MSH2, MSH6, and PMS2 cause LS. ${ }^{19,207}$ Also, deletions of the terminal codon of the EPCAM gene, located just upstream from the MSH2 gene, result in silencing of the MSH2 gene in tissues that express EPCAM and, consequently, produce a phenotype very similar to LS. ${ }^{208}$ The BRAF gene, a member of the RAF-RAS gene family, encodes a cytoplasmic serine/threonine kinase, an important component of the mitogen-activated protein kinase signaling pathway. Somatic mutations in the BRAF gene, largely at codon 600 , are noted in $15 \%$ of sporadic CRCs. These are CRCs that develop through a methylation pathway called $\mathrm{CpG}$ island methylator phenotype. These cancers can also demonstrate MSI-high through somatic promoter methylation of MLH1. ${ }^{206}$

Panel testing for germline mutations in O20 cancercausing genes (which include the MMR and EPCAM genes) is now available commercially as a single test. Inevitably, advances in technology will decrease the cost of such analysis. In the future, germline testing, rather than tumor evaluation, might be the most cost-effective universal testing approach. Germline testing of individuals for a deleterious mutation in MLH1, MSH2, MSH6, PMS2, or EPCAM genes has several benefits. First, it can confirm the diagnosis of LS in a patient and/or family. Second, it can determine the status of at-risk family members in pedigrees where the pathogenic mutation has been found. Third, it can direct the management of affected and unaffected individuals. ${ }^{206}$

Identifying and evaluating families for LS is increasing in complexity due to the recognition that: family history-based clinical criteria lack sensitivity and specificity; genetic testing for LS continues to evolve as understanding of the molecular mechanisms underlying it evolves; and the LS phenotype encompasses multiple organ systems and demonstrates overlap with other hereditary cancer syndromes. ${ }^{209}$ Predictive biomarkers are central to the concept of precision cancer medicine. Such validated predictive biomarkers such as BRCA1, BRCA2, and the MMR germline mutations in LS, among others, can often be effectively employed in the selection of individual patients for targeted treatment. For example, patients with BRCA mutations respond better to PARP inhibitors ${ }^{210}$ and LS metastatic patients respond better to anti PD- $1^{211}$. On the other hand, a prognostic biomarker such as cancer stage or grade will be limited to providing statistical probability inclusive of survival estimates. ${ }^{204}$

\section{Conclusion}

We now know precisely what causes cancer: a sequential series of alterations in well-defined genes that alter the function of a limited number of pathways. Moreover, we know that this process takes decades to develop and that the incurable stage, metastasis, occurs only a few years before death. From a technical standpoint, the development of new and improved methods for early detection and prevention will not be easy, but there is no reason to assume that it will be more difficult than the development of new therapies aimed at treating widely metastatic disease. We believe that cancer deaths can be reduced by more than $75 \%$ in the coming decades, but that this reduction will only come about if greater efforts are made toward early detection and prevention.

\section{References}

1. Weinstein JN, Collisson EA, Mills GB, Shaw KRM, Ozenberger BA, et al. The Cancer Genome Atlas Pan-Cancer analysis project. Nat Genet. 2013; 45(10): 1113-20.

2. Soda M, Choi YL, Enomoto M, Takada S, Yamashita Y, Ishikawa S, et al. Identification of the transforming EML4-ALK fusion gene in non-small-cell lung cancer. Nature. 2007; 448(7153): 561-6.

3. Parada LF, Tabin CJ, Shih C, Weinberg RA. Human EJ bladder carcinoma oncogene is homologue of Harvey sarcoma virus ras gene. Nature. 1982; 297(5866): 474-8.

4. Payne GS, Bishop JM, Varmus HE. Multiple arrangements of viral DNA and an activated host oncogene in bursal lymphomas. Nature. 1982; 295: 209-14.

5. Baker SJ, Fearon ER, Nigro JM, Hamilton SR, Preisinger AC, Jessup $\mathrm{JM}$, et al. Chromosome 17 deletions and $\mathrm{p} 53$ gene mutations in colorectal carcinomas. Science. 1989; 244(4901): 217-21.

6. Tomlins SA, Rhodes DR, Perner S, Dhanasekaran SM, Mehra R, Sun $\mathrm{XW}$, et al. Recurrent fusion of TMPRSS2 and ETS transcription factor genes in prostate cancer. Science. 2005; 310(5748): 644-8.

7. Davies H, Bignell GR, Cox C, Stephens P, Edkins S, Clegg S, et al. Mutations of the BRAF gene in human cancer. Nature. 2002; 417(6892): 949-54.

8. Mardis ER, Ding L, Dooling DJ, Larson DE, McLellan MD, Chen K, et al. Recurring mutations found by sequencing an acute myeloid leukemia genome. N Engl J Med. 200; 361(11): 1058-66.

9. The Cancer Genome Atlas Research Network. Comprehensive genomic characterization defines human glioblastoma genes and core pathways. Nature. 2008; 455(7216): 1061-8. 
10. The Cancer Genome Atlas Research Network. Integrated genomic analyses of ovarian carcinoma. Nature. 2011; 474(7353): 609-15.

11. The Cancer Genome Atlas Research Network. Comprehensive molecular portraits of human breast tumours. Nature. 2012; 490(7418): 61-70.

12. The Cancer Genome Atlas Research Network. Comprehensive genomic characterization of squamous cell lung cancers. Nature. 2012; 489(7417): 519-25.

13. The Cancer Genome Atlas Research Network. Comprehensive molecular characterization of human colon and rectal cancer. Nature. 2012; 487(7407): 330-7.

14. Perou C, Sørlie T, Eisen M, van de Rijn M, Jeffrey SS, Rees CA, et al. Molecular portraits of human breast tumours. Nature. 2000; 406 : $747-752$.

15. The Cancer Genome Atlas Research Network. Comprehensive molecular characterization of clear cell renal cell carcinoma. Nature. 2013; 499(7456): 43-9.

16. Vogelstein B, Papadopoulos N, Velculescu VE, Zhou S, Diaz LA, Kinzler KW. Cancer Genome Landscapes. Science. 2013; 339(6127): $1546-58$

17. Hanahan D, Weinberg RA. Hallmarks of cancer: the next generation. Cell. 2011; 144: 646-74.

18. Baylin SB, Jones PA. A decade of exploring the cancer epigenome - biological and translational implications. Nat Rev Cancer. 2011; 11(10): 726-34.

19. Sandoval J, Esteller M. Cancer epigenomics: beyond genomics. Curr Opin Genet Dev. 2012; 22(1): 50-5.

20. Jones PA, Baylin SB. The epigenomics of cancer. Cell. 2007; 128(4): 683-92.

21. Kelly TK, De Carvalho DD, Jones PA. Epigenetic modifications as therapeutic targets. Nat Biotechnol. 2010; 28(10): 1069-78.

22. De Carvalho DD, Sharma S, You JS, Su SF, Taberlay PC, Kelly TK, et al. DNA methylation screening identifies driver epigenetic events of cancer cell survival. Cancer Cell. 2012; 21(5): 655-67.

23. Kalari S, Pfeifer GP. Identification of driver and passenger DNA methylation in cancer by epigenomic analysis. In: Advances in Genetics. Amsterdam: Elsevier; 2010. p.277-308.

24. You JS, Jones PA. Cancer genetics and epigenetics: two sides of the same coin? Cancer Cell. 2012; 22(1): 9-20.

25. Lynch HT, Shaw MW, Magnuson CW, Larsen AL, Krush AJ. Hereditary factors in cancer: study of two large midwestern kindreds. Arch Intern Med 1966; 117(2): 206-12.

26. Risch N, Merikangas K. The future of genetic studies of complex human diseases. Science. 1996; 273(5281): 1516-7.

27. Foulkes WD. Inherited susceptibility to common cancers. N Engl J Med 2008; 359(20): 2143-53.

28. Bartkova J, Horejsi Z, Koed K, Kramer A, Tort F, Zieger K, et al. DNA damage response as a candidate anti-cancer barrier in early human tumorigenesis. Nature. 2005; 434(7035): 864-70.

29. Bartkova J, Rezaei N, Liontos M, Karakaidos P, Kletsas D, Issaeva $\mathrm{N}$, et al. Oncogene-induced senescence is part of the tumorigenesis bar- rier imposed by DNA damage checkpoints. Nature 2006; 444(7119): 633-7.

30. Gorgoulis VG, Vassiliou LV, Karakaidos P, Zacharatos P, Kotsinas A, Liloglou T, et al. Activation of the DNA damage checkpoint and genomic instability in human precancerous lesions. Nature 2005; 4349(7035): 907-13.

31. Burrell RA, McClelland SE, Endesfelder D, Groth P, Weller MC, Shaikh N, et al. Replication stress links structural and numerical cancer chromosomal instability. Nature 2013; 494(7438): 492-6.

32. Kanu N, Cerone MA, Goh G, Zalmas LP, Bartkova J, Dietzen M, et al. DNA replication stress mediates APOBEC3 family mutagenesis in breast cancer. Genome Biol 2016; 17(1): 185. doi: 10.1186/ s13059-016-1042-9.

33. Fragkos M, Ganier O, Coulombe P, Mechali M. DNA replication origin activation in space and time. Nat Rev Mol Cell Biol 2015; 16(6): 360-74.

34. Kotsantis P, Petermann E, Boulton SJ. Mechanisms of oncogeneinduced replication stress: jigsaw falling into place. Cancer Discov. 2018; 8(5): 537-55.

35. Macheret M, Halazonetis TD. DNA replication stress as a hallmark of cancer. Annu Rev Pathol. 2015; 10(1): 425-48.

36. Gonzalez S, Klatt P, Delgado S, Conde E, Lopez-Rios F, SanchezCespedes M, et al. Oncogenic activity of Cdc6 through repression of the INK4/ARF locus. Nature. 2006; 440(7084): 702-6.

37. Land H, Parada LF, Weinberg RA. Tumorigenic conversion of primary embryo fibroblasts requires at least two cooperating oncogenes. Nature. 1983; 304(5927): 596-602

38. Serrano M, Lin AW, McCurrach ME, Beach D, Lowe SW. Oncogenic ras provokes premature cell senescence associated with accumulation of p53 and p16INK4a. Cell. 1997; 88(5): 593-602.

39. Meek DW. Tumour suppression by p53: a role for the DNA damage response? Nat Rev Cancer. 2009; 9(10): 714-23.

40. Brosens LA, Hackeng WM, Offerhaus GJ, Hruban RH, Wood LD. Pancreatic adenocar- cinoma pathology: changing "landscape." J Gastrointest Oncol. 2015; 6(4): 358-74. h

41. Ojesina AI, Lichtenstein L, Freeman SS, Pedamallu CS, ImazRosshandler I, Pugh TJ, et al. Landscape of genomic alterations in cervical carcinomas. Nature. 2014; 506(7488): 371-5.

42. Vogelstein B, Kinzler KW. The path to cancer - three strikes and you're out. N Engl J Med. 2015; 373(20): 1895-8.

43. Muller PA Vousden KH. P53 mutations in cancer. Nat Cell Biol. 2013; 15(1): 2-8.

44. Wu H, Zhang Y. Mechanisms and functions of Tet protein-mediated 5-methylcytosine oxidation. Genes Dev. 2011; 25(23): 2436-52.

45. Kouzarides T. Chromatin modifications and their function. Cell. 2007; 128(4): 693-705.

46. Tan M, Luo H, Lee S, Jin F, Yang JS, Montellier E, et al. Identification of 67 histone marks and histone lysine crotonylation as a new type of histone modification. Cell. 2011; 146(6): 1016-28.

47. Dawson MA, Kouzarides T. Cancer epigenetics: from mechanism to therapy. Cell. 2012; 150(1): 12-27.

48. Morin RD, Johnson NA, Severson TM, Mungall AJ, An J, Goya $\mathrm{R}$, et al. Somatic mutations altering EZH2 (Tyr641) in follicular and diffuse large B-cell lymphomas of germinal-center origin. Nat Genet. 2010; 42(2): 181-5.

49. Van Haaften G, Dalgliesh GL, Davies H, Chen L, Bignell G, Greenman $\mathrm{C}$, et al. Somatic mutations of the histone H3K27 demethylase gene UTX in human cancer. Nat Genet. 2009; 41(5): 521-3.

50. Baylin SB, Herman JG. DNA hypermethylation in tumorigenesis: epigenetics joins genetics. Trends Genet. 2000; 16: 168-74.

51. Jones PA, Laird PW. Cancer-epigenetics comes of age. Nat Genet. 1999; 21(2): 163-7.

52. Esteller M, Toyota M, Sanchez-Cespedes M, Capella G, Peinado MA, Watkins DN, et al. Inactivation of the DNA repair gene O6-methylguanine-DNA methyltransferase by promoter hypermethylation is associated with $\mathrm{G}$ to A mutations in K-ras in colorectal tumorigenesis. Cancer Res. 2000; 60(9): 2368-71 
53. Herman JG, Civin CI, Issa JP, Collector MI, Sharkis SJ, Baylin SB. Distinct patterns of inactivation of p15INK4B and p16INK4A characterize the major types of hematological malignancies. Cancer Res. 1997; 57(5): 837-41.

54. Burbee DG, Forgacs E, Zochbauer-Muller S, Shivakumar L, Fong $\mathrm{K}$, Gao B, et al. Epigenetic inactivation of RASSF1A in lung and breast cancers and malignant phenotype suppression. J Natl Cancer Inst. 2001; 93(9): 691-9.

55. Dammann R, Li C, Yoon JH, Chin PL, Bates S, Pfeifer GP. Epigenetic inactivation of a RAS association domain family protein from the lung tumour suppressor locus 3p21.3. Nat Genet. 2000; 25(3): 3159.

56. Jones PA, Balin SB. The fundamental role of epigenetic events in cancer. Nat Rev Genet. 2002; 3(6): 415-28.

57. Li E, Bestor TH, Jaenisch R. Targeted mutation of the DNA methyltransferase gene results in embryonic lethality. Cell. 1992; 69(6): 915-26.

58. Okano M, Bell DW, Haber DA, Li E. DNA methyltransferases Dnmt3a and Dnmt3b are essential for de novo methylation and mammalian development. Cell.1999; 99(3): 247-57.

59. Klose RJ, Bird AP. Genomic DNA methylation: the mark and its mediators. Trends Biochem Sci. 2006; 31(2): 89-97.

60. Moran-Crusio K, Reavie L, Shih A, Abdel-Wahab O, Ndiaye-Lobry $\mathrm{D}$, Lobry C, et al. Tet2 loss leads to increased hematopoietic stem cell self-renewal and myeloid transformation. Cancer Cell. 2011; 20(1): 11-24.

61. Quivoron C, Couronné L, Della Valle V, Lopez CK, Plo I, Wagner-Ballon $\mathrm{O}$, et al. TET2 inactivation results in pleiotropic hematopoietic abnormalities in mouse and is a recurrent event during human lymphomagenesis. Cancer Cell. 2011; 20(1): 25-38.

62. Patel JP, Gönen M, Figueroa ME, Fernandez H, Sun Z, Racevskis J, et al. Prognostic relevance of integrated genetic profiling in acute myeloid leukemia. N Engl J Med. 2012; 366(12): 1079-89.

63. Johnstone RW, Licht JD. Histone deacetylase inhibitors in cancer therapy. Cancer Cell. 2003; 4(1): 13-8.

64. Bereshchenko OR, Gu W, Dalla-Favera R. Acetylation inactivates the transcriptional repressor BCL6. Nat Genet. 2002; 32(4): 606-13.

65. Federico M, Bagella L. Histone deacetylase inhibitors in the treatment of hematological malignancies and solid tumors. J Biomed Biotechnol. 2011; 2011: 475641. doi: 10.1155/2011/475641.

66. Timp W, Feinberg AP. Cancer as a dysregulated epigenome allowing cellular growth advantage at the expense of the host. Nat Rev Cancer/ 2013; 13(7): 497-510.

67. Esteller M. Cancer epigenomics: DNA methylomes and histonemodification maps. Nat Rev Genet. 2007; 8(4): 286-98.

68. Krivtsov AV, Armstrong SA. MLL translocations, histone modifications and leukaemia stem-cell development. Nat Rev Cancer. 2007; 7(11): 823-33.

69. Hitchins MP, Rapkins RW, Kwok CT, Srivastava S, Wong JJL, Khachigian LM, et al. Dominantly inherited constitutional epigenetic silencing of mlh1 in a cancer-affected family is linked to a single nucleotide variant within the $5^{\prime}$ UTR. Cancer Cell. 2011; 20(2): 200-13.

70. Kanai Y, Ushijima S, Nakanishi Y, Sakamoto M, Hirohashi S. Mutation of the DNA methyltransferase (DNMT) 1 gene in human colorectal cancers. Cancer Lett. 2003; 192(1): 75-82.

71. Ley TJ, Ding L, Walter MJ, McLellan MD, Lamprecht T, Larson DE, et al. DNMT3A mutations in acute myeloid leukemia. N Engl J Med. 2010; 363(25): 2424-33.
72. Yamashita Y, Yuan J, Suetake I, Suzuki H, Ishikawa Y, Choi YL, et al. Array-based genomic resequencing of human leukemia. Oncogene. 2010; 29(25): 3723-31.

73. Yan XJ, Xu J, Gu ZH, Pan CM, Lu G, Shen Y, et al. Exome sequencing identifies somatic mutations of DNA methyltransferase gene DNMT3A in acute monocytic leukemia. Nat Genet. 2011; 43: 309-15.

74. Wijmenga C, Hansen RS, Gimelli G, Björck EJ, Davies EG, Valentine $\mathrm{D}$, et al. Genetic variation in ICF syndrome: evidence for genetic heterogeneity. Hum Mutat. 2000; 16(6): 509-17.

75. Shen H, Wang L, Spitz MR, Hong WK, Mao L, Wei Q. A novel polymorphism in human cytosine DNA-methyltransferase-3B promoter is associated with an increased risk of lung cancer. Cancer Res. 2002; 62(17): 4992-5.

76. Brock MV, Hooker CM, Ota-Machida E, Han Y, Guo M, Ames S, et al. DNA methylation markers and early recurrence in stage i lung cancer. N Engl J Med. 2008; 358(11): 1118-28.

77. Tomasetti C, Marchionni L, Nowak MA, Parmigiani G, Vogelstein B. Only three driver gene mutations are required for the development of lung and colorectal cancers. Proc Natl Acad Sci USA. 2014; 112(1): 118-23.

78. Garraway LA, Lander ES. Lessons from the cancer genome. Cell. 2013; 153(1): 17-37.

79. Stratton MR, Campbell PJ, Futreal PA. The cancer genome. Nature. 2009; 458(7239): 719-24.

80. Tomasetti C, Vogelstein B, Parmigiani G. Half or more of the somatic mutations in cancers of self-renewing tissues originate prior to tumor initiation. Proc Natl Acad Sci USA 2013; 110(6): 1999-2004.

81. Davoli T, Xu AW, Mengwasser KE, Sack LM, Yoon JC, Park PJ, et al. Cumulative haploinsufficiency and triplosensitivity drive aneuploidy patterns and shape the cancer genome. Cell. 2013; 155(4): 948-62.

82. Sawyers CL. Chronic myeloid leukemia. N Engl J Med. 1999; 340(17): 1330-40.

83. Shukron O, Vainstein V, Kündgen A, Germing U, Agur Z. Analyzing transformation of myelodysplastic syndrome to secondary acute myeloid leukemia using a large patient database. Am J Hematol. 2012; 87(9): 853-60.

84. Sanchez-Vega F, Mina M, Armenia J, Chatila WK, Luna A, La KC, et al. Oncogenic signaling pathways in The Cancer Genome Atlas. 2018; 173(2): 321-337.e10.

85. Moore PS, Chang Y. Why do viruses cause cancer? Highlights of the first century of human tumour virology. Nat Rev Cancer. 2010; 10(12): 878-89.

86. Krump NA, You J. Molecular mechanisms of viral oncogenesis in humans. Nat Rev Microbiol. 2018; 16(11): 684-98.

87. Ménézo Y, Dale B, Cohen M. DNA damage and repair in human oocytes and embryos: a review. Zygote. 2010; 18(4): 357-65.

88. Jackson SP, Bartek J. The DNA-damage response in human biology and disease. Nature. 2009; 461(7267): 1071-8.

89. Ciccia A, Elledge SJ. The DNA damage response: making it safe to play with knives. Mol Cell. 2010; 40(2): 179-204.

90. Lahtz C, Pfeiffer GP. Epigenetic changes of DNA repair genes in cancer. J Mol Cell Biol. 2011; 30(1): 51-8.

91. Pfeifer GP. Mutagenesis at methylated $\mathrm{CpG}$ sequences. Curr Top Microbiol Immunol. 2006; 301: 259-81.

92. Hendrich B, Bird A. Identification and characterization of a family of mammalian methyl-CpG binding proteins. Mol Cel Biol. 1998; 18(11): 6538-47. 
93. Hendrich B, Hardeland U, Ng H-H, Jiricny J, Bird A. The thymine glycosylase MBD4 can bind to the product of deamination at methylated CpG sites. Nature. 1999; 401(6750): 301-4.

94. Peng B, Hurt EM, Hodge DR, Thomas SB, Farrar WL. DNA hypermethylation and partial gene silencing of human thymineDNA glycosylase in multiple myeloma cell lines. Epigenetics. 2006; 1(3): 138-45.

95. Howard JH, Frolov A, Tzeng C-WD, Stewart A, Midzak A, Majmundar A, et al. Epigenetic downregulation of the DNA repair gene MED1/MBD4 in colorectal and ovarian cancer. Cancer Biol Ther. 2009; 8(1): 94-100.

96. Arai K, Morishita K, Shinmura K, Kohno T, Kim S-R, Nohmi T, et al. Cloning of a human homolog of the yeast OGG1 gene that is involved in the repair of oxidative DNA damage. Oncogene. 1997; 14(23): 2857-61.

97. Chevillard S, Radicella JP, Levalois C, Lebeau J, Poupon MF, Oudard S, et al. Mutations in OGG1, a gene involved in the repair of oxidative DNA damage, are found in human lung and kidney tumours. Oncogene. 1998; 16(23): 3083-6.

98. Shinmura K, Yokota J. The OGG1 gene encodes a repair enzyme for oxidatively damaged dna and is involved in human carcinogenesis. Antioxid Redox Signal. 2001; 3(4): 597-609.

99. Guan H, Ji M, Hou P, Liu Z, Wang C, Shan Z, et al. Hypermethylation of the DNA mismatch repair gene MLH1 and Its association with lymph node metastasis and T1799ABRAF mutation in patients with papillary thyroid cancer. Cancer. 2008; 113(2): 247-55.

100. Tano K, Shiota S, Collier J, Foote RS, Mitra S. Isolation and structural characterization of a cDNA clone encoding the human DNA repair protein for O6-alkylguanine. Proc Natl Acad Sci USA. 1990; 87(2): 686-90.

101. Natarajan AT, Vermeulen S, Darroudi F, Valentine MB, Brent TP, Mitra $\mathrm{S}$, et al. Chromosomal localization of human O6-methylguanineDNA methyltransferase (MGMT) gene by in situ hybridization. Mutagenesis. 1992; 7(1): 83-5.

102. Esteller M, Hamilton SR, Burger PC, Baylin SB, Herman JG. Inactivation of the DNA repair gene O6-methylguanine-DNA methyltransferase by promoter hypermethylation is a common event in primary human neoplasia. Cancer Res. 1999; 59(4): 793-7.

103. Mellai M, Caldera V, Annovazzi L, Chiò A, Lanotte M, Cassoni $\mathrm{P}$, et al. MGMT promoter hypermethylation in a series of 104 glioblastomas. Cancer Genom Proteom. 2009; 6(4): 219-27.

104. Shamsara J, Sharif S, Afsharnezhad S, Lotfi M, Raziee HR, Ghaffarzadegan K, et al. Association between MGMT promoter hypermethylation and 53 mutation in glioblastoma. Cancer Invest. 2009; 27(8): 825-9.

105. Herfarth KK, Brent TP, Danam RP, Remack JS, Kodner IJ, Wells SA $\mathrm{Jr}$, et al. A specific $\mathrm{CpG}$ methylation pattern of the MGMT promoter region associated with reduced MGMT expression in primary colorectal cancers. Mol Carcinog. 1999; 24(2): 90-8.

106. Ogino S, Meyerhardt JA, Kawasaki T, Clark JW, Ryan DP, Kulke $\mathrm{MH}$, et al. $\mathrm{CpG}$ island methylation, response to combination chemotherapy, and patient survival in advanced microsatellite stable colorectal carcinoma. Virchows Archiv. 2007; 450(5): 529-37.

107. Wolf P, Hu YC, Doffek K, Sidransky D, Ahrendt SA. O(6)Methylguanine-DNA methyltransferase promoter hypermethylation shifts the p53 mutational spectrum in non-small cell lung cancer. Cancer Res. 2001; 61(22): 8113-7.

108. Wu JY, Wang J, Lai JC, Cheng YW, Yeh KT, Wu TC, et al. Association of O6-methylguanine-DNA methyltransferase (MGMT) promoter methylation with $\mathrm{p} 53$ mutation occurrence in non-small cell lung cancer with different histology, gender, and smoking status. Ann Surg Oncol. 2008; 15(11): 3272-7.

109. Oue N, Shigeishi H, Kuniyasu H, Yokozaki H, Kuraoka K, Ito R, et al. Promoter hypermethylation of MGMT is associated with protein loss in gastric carcinoma. Int J Cancer. 2001; 93(6): 805-9.

110. Goldenberg D, Harden S, Masayesva BG, Ha P, Benoit N, Westra $\mathrm{WH}$, et al. Intraoperative molecular margin analysis in head and neck cancer. Arch Otolaryngol Head Neck Surg. 2004; 130(1): 3944.

111. Maruya S, Issa JPJ, Weber RS, Rosenthal DI, Haviland JC, Lotan R, et al. Differential methylation status of tumor-associated genes in head and neck squamous carcinoma. Clin Cancer Res. 2004; 10(11): 3825-30.

112. Steinmann K, Sandner A, Schagdarsurengin U, Dammann RH. Frequent promoter hypermethylation of tumor-related genes in head and neck squamous cell carcinoma. Oncol Rep. 2009; 22(6): 151926.

113. Sugasawa K. A multistep damage recognition mechanism for global genomic nucleotide excision repair. Genes Dev. 2001; 15(5): 50721.

114. Riedl T. The comings and goings of nucleotide excision repair factors on damaged DNA. EMBO J. 2003; 22(19): 5293-303.

115. Fousteri M, Mullenders LH. Transcription-coupled nucleotide excision repair in mammalian cells: molecular mechanisms and biological effects. Cell Res. 2008; 18(1): 73-84.

116. Hanawalt PC, Spivak G. Transcription-coupled DNA repair: two decades of progress and surprises. Nat Rev Mol Cell Biol. 2008; 9(12): 958-70.

117. Peng B, Hodge DR, Thomas SB, Cherry JM, Munroe DJ, Pompeia C, et al. Epigenetic silencing of the human nucleotide excision repair gene, hHR23B, in interleukin-6-responsive multiple myeloma KAS-6/1 cells. J Biol Chem.2005; 280(6): 4182-7.

118. Chen HY, Shao CJ, Chen FR, Kwan AL, Chen ZP. Role of ERCC1 promoter hypermethylation in drug resistance to cisplatin in human gliomas. Int J Cancer. 2009; 126(8): 1944-54.

119. Bronner CE, Baker SM, Morrison PT, Warren G, Smith LG, Lescoe $\mathrm{MK}$, et al. Mutation in the DNA mismatch repair gene homologue hMLH 1 is associated with hereditary non-polyposis colon cancer. Nature. 1994; 368(6468): 258-61.

120. Gazzoli I, Loda M, Garber J, Syngal S, Kolodner RD. A hereditary nonpolyposis colorectal carcinoma case associated with hypermethylation of the MLH1 gene in normal tissue and loss of heterozygosity of the unmethylated allele in the resulting microsatellite instability-high tumor. Cancer Res. 2002; 62(14): 3925-8.

121. Suter CM, Martin DIK, Ward RL. Germline epimutation of MLH1 in individuals with multiple cancers. Nat Genet. 2004; 36(5): 497501

122. Hitchins MP, Wong JJ, Suthers G, Suter CM, Martin DI, Hawkins $\mathrm{NJ}$, et al. Inheritance of a cancer-associated MLH1 germ-line epimutation. N Engl J Med. 2007; 356(7): 697-705.

123. Duncan JA, Reeves JR, Cooke TG. BRCA1 and BRCA2 proteins: roles in health and disease. Mol Pathol. 1998; 51(5): 237-47.

124. Yoshida K, Miki Y. Role of BRCA1 and BRCA2 as regulators of DNA repair, transcription, and cell cycle in response to DNA damage. Cancer Sci. 2004; 95(11): 866-71.

125. Dobrovic A, Simpfendorfer D. Methylation of the BRCA1 gene in sporadic breast cancer. Cancer Res. 1997; 57(16): 3347-50.

126. Gras E, Cortes J, Diez O, Alonso C, Matias-Guiu X, Baiget M, et al. Loss of heterozygosity on chromosome 13q12-q14, BRCA- 
2 mutations and lack of BRCA-2 promoter hypermethylation in sporadic epithelial ovarian tumors. Cancer. 2001; 92(4): 787-95.

127. Hilton JL, Geisler JP, Rathe JA, Hattermann-Zogg MA, DeYoung B, Buller RE. Inactivation of BRCA1 and BRCA2 in ovarian cancer. J Natl Cancer Inst. 2002; 94(18) :1396-406.

128. Bernal C, Vargas M, Ossandón F, Santibáñez E, Urrutia J, Luengo $\mathrm{V}$, et al. DNA methylation profile in diffuse type gastric cancer: evidence for hypermethylation of the BRCA1 promoter region in early-onset gastric carcinogenesis. Biol Res. 2008;41(3): 303-15.

129. Lee MN, Tseng RC, Hsu HS, Chen JY, Tzao C, Ho WL, et al. Epigenetic inactivation of the chromosomal stability control genes BRCA1, BRCA2, and XRCC5 in non-small cell lung cancer. Clin Cancer Res. 2007; 13(3): 832-8.

130. Xing D, Scangas G, Nitta M, He L, Xu X, Ioffe YJM, et al. A role for BRCA1 in uterine leiomyosarcoma. Cancer Res. 2009; 69(21): 8231-5.

131. Yu J, Zhu T, Wang Z, Zhang H, Qian Z, Xu H, et al. A novel set of DNA methylation markers in urine sediments for sensitive/specific detection of bladder cancer. Clin Cancer Res. 2007; 13(24): 7296304.

132. Taccioli G, Gottlieb T, Blunt T, Priestley A, Demengeot J, Mizuta R, et al. Ku80: product of the XRCC5 gene and its role in DNA repair and V(D)J recombination. Science. 1994; 265(5177): 1442-5.

133. Difilippantonio MJ, Zhu J, Chen HT, Meffre E, Nussenzweig MC, Max EE, et al. DNA repair protein Ku80 suppresses chromosomal aberrations and malignant transformation. Nature. 2000; 404(6777): $510-4$.

134. Koike M. Dimerization, translocation and localization of Ku70 and Ku80 proteins. J Radiat Res. 2002; 43(3): 223-36.

135. Carter T, Vancurová I, Sun I, Lou W, DeLeon S. A DNA-activated protein kinase from HeLa cell nuclei. Mol Cell Biol. 1990; 10(12): 6460-71.

136. Kim W, Vo QN, Shrivastav M, Lataxes TA, Brown KD. Aberrant methylation of the ATM promoter correlates with increased radiosensitivity in a human colorectal tumor cell line. Oncogene. 2002; 21(24): 3864-71.

137. Vo QN, Kim WJ, Cvitanovic L, Boudreau DA, Ginzinger DG, Brown $\mathrm{KD}$. The ATM gene is a target for epigenetic silencing in locally advanced breast cancer. Oncogene. 2004; 23(58): 9432-7.

138. Matsuoka S. Linkage of ATM to Cell Cycle Regulation by the Chk2 Protein Kinase. Science. 1998; 282(5395): 1893-7.

139. Kim DS, Kim MJ, Lee JY, Lee SM, Choi JE, Lee SY, et al. Epigenetic inactivation of checkpoint kinase 2 gene in non-small cell lung cancer and its relationship with clinicopathological features. Lung Cancer. 2009; 65(2): 247-50.

140. Zhang P, Wang J, Gao W, Yuan BZ, Rogers J, Reed E. CHK2 kinase expression is down-regulated due to promoter methylation in nonsmall cell lung cancer. Mol Cancer. 2004; 3: 14. doi: 10.1186/14764598-3-14.

141. Wang H, Wang S, Shen L, Chen Y, Zhang X, Zhou J, et al. Chk2 down-regulation by promoter hypermethylation in human bulk gliomas. Life Sci. 2010; 86(5-6): 185-91.

142. Martincorena I, Campbell PJ. Somatic mutation in cancer and normal cells. Science. 2015; 349(6255): 1483-9.

143. Potapova TA, Zhu J, Li R. Aneuploidy and chromosomal instability: a vicious cycle driving cellular evolution and cancer genome chaos. Cancer Metastasis Rev. 2013; 32(3-4): 377-89.

144. Macaluso M, Paggi MG, Giordano A. Genetic and epigenetic alterations as hallmarks of the intricate road to cancer. Oncogene. 2003; 22(42): 6472-6478.
145. Baxter E, Windloch K, Gannon F, Lee JS. Epigenetic regulation in cancer progression. Cell Biosci. 2014; 4(1): 45. doi: 10.1186/20453701-4-45.

146. MDuff FKE, Turner SD. Jailbreak: Oncogene-induced senescence and its evasion. Cell Signal. 2011; 23(1): 6-13.

147. Sun W, Yang J. Functional mechanisms for human tumor suppressors. J Cancer. 2010; 1: 136-40.

148. Wang LH, Wu CF, Rajasekaran N, Shin YK. Loss of tumor suppressor gene function in human cancer: an overview. Cell Physiol Biochem. 2018; 51(6): 2647-93.

149. Sánchez-Rivera FJ, Papagiannakopoulos T, Romero R, Tammela $\mathrm{T}$, Bauer MR, Bhutkar A, et al. Rapid modelling of cooperating genetic events in cancer through somatic genome editing. Nature. 2014; 516(7531): 428-31.

150. Walter DM, Venancio OS, Buza EL, Tobias JW, Deshpande C, Gudiel $\mathrm{AA}$, et al. Systematic in vivo inactivation of chromatin-regulating enzymes identifies setd 2 as a potent tumor suppressor in lung adenocarcinoma. Cancer Res. 2017; 77(7): 1719-29.

151. Kim J, Minna JD. Evaluating tumor-suppressor gene combinations. Nat Genet. 2018; 50(4): 480-2.

152. Rogers ZN, McFarland CD, Winters IP, Seoane JA, Brady JJ, Yoon S, et al. Mapping the in vivo fitness landscape of lung adenocarcinoma tumor suppression in mice. Nat Genet. 2018; 50(4): 483-486.

153. Peller S, Rotter V. TP53 in hematological cancer: low incidence of mutations with significant clinical relevance. Hum Mut 2003; 21(3): 277-284.

154. Brachman DG, Graves D, Vokes E, Beckett M, Haraf D, Montag A, et al. Occurrence of $\mathrm{p} 53$ gene deletions and human papilloma virus infection in human head and neck cancer. Cancer Res. 1992; 52(17): 4832-6.

155. Hock AK, Vousden KH. The role of ubiquitin modification in the regulation of p53. BBA-Mol Cell Res. 2014; 1843(1): 137-49.

156. Pei D, Zhang Y, Zheng J. Regulation of $\mathrm{p} 53$ : a collaboration between Mdm2 and MdmX. Oncotarget. 2012; 3(3): 228-35.

157. Kon N, Kobayashi Y, Li M, Brooks CL, Ludwig T, Gu W. Inactivation of HAUSP in vivo modulates p53 function. Oncogene. 2010; 29(9): 1270-9.

158. Marine JC. Spotlight on the role of COP1 in tumorigenesis. Nat Rev Cancer. 2012; 12(7): 455-64.

159. Jung YS, Qian Y, Chen X. Pirh2 RING-finger E3 ubiquitin ligase: Its role in tumorigenesis and cancer therapy. FEBS Lett. 2012; 586(10): 1397-402. 160. Zhang X, Berger FG, Yang J, Lu X. USP4 inhibits p53 through deubiquitinating and stabilizing ARFBP1. The EMBO J 2011; 30(11): 2177-89.

161. Hampel H, Frankel WL, Martin E, Arnold M, Khanduja K, Kuebler $\mathrm{P}$, et al. Feasibility of screening for lynch syndrome among patients with colorectal cancer. J Clin Oncol. 2008; 26(35): 5783-8.

162. Blue Ribbon Panel. Cancer Moonshot Blue Ribbon Panel Report 2016. USA: Blue Ribbon Panel; 2016.

163. Aaltonen LA, Salovaara R, Kristo P, Canzian F, Hemminki A, Peltomäki $\mathrm{P}$, et al. Incidence of hereditary nonpolyposis colorectal cancer and the feasibility of molecular screening for the disease. $\mathrm{N}$ Engl J Med. 1998; 338(21): 1481-7.

164. Barnetson RA, Tenesa A, Farrington SM, Nicholl ID, Cetnarskyj $\mathrm{R}$, Porteous ME, et al. Identification and survival of carriers of mutations in dna mismatch-repair genes in colon cancer. N Engl J Med. 2006; 354(26): 2751-63.

165. Hampel H, Frankel WL, Martin E, Arnold M, Khanduja K, Kuebler $\mathrm{P}$, et al. Screening for the lynch syndrome (hereditary nonpolyposis colorectal cancer). N Engl J Med. 2005; 352(18): 1851-60. 
166. Pinol V, Castells A, Andreu M, Castellví-Bel S, Alenda C, Llor X, et al. Accuracy of revised Bethesda guidelines, microsatellite instability, and immunohistochemistry for the identification of patients with hereditary nonpolyposis colorectal cancer. JAMA. 2005; 293(16): 1986-94.

167. Salovaara R, Loukola A, Kristo P, Kääriäinen H, Ahtola H, Eskelinen $\mathrm{M}$, et al. Population-based molecular detection of hereditary nonpolyposis colorectal cancer. J Clin Oncol. 2000; 18(11): 2193 200.

168. Bonadona V, Bonaïti B, Olschwang S, Grandjouan S, Huiart L, Longy $\mathrm{M}$, et al. Cancer risks associated with germline mutations in MLH1, MSH2, and MSH6 genes in Lynch syndrome. JAMA. 2011; 305(22): 2304-10.

169. Dunlap MG, Farrington SM, Carothers AD, Wyllie AH, Sharp L, Burn J, et al. Cancer risk associated with germline DNA mismatch repair gene mutations. Hum Mol Genet. 1997; 6(1): 105-10.

170. Hendriks YMC, Wagner A, Morreau H, Menko F, Stormorken A, Quehenberger F, et al. Cancer risk in hereditary nonpolyposis colorectal cancer due to MSH6 mutations: impact on counseling and surveillance. Gastroenterology. 2004; 127(1): 17-25.

171. Senter L, Clendenning M, Sotamaa K, Hampel H, Green J, Potter JD, et al. The clinical phenotype of lynch syndrome due to germ-line PMS2 mutations. Gastroenterology. 2008; 135(2): 419-428.e1.

172. Vasen HFA. Clinical description of the lynch syndrome [Hereditary Nonpolyposis Colorectal Cancer (HNPCC)]. Fam Cancer. 2005; 4(3): 219-25.

173. Hampel H, Stephens J, Pukkala E, Sankila R, Aaltonen L, Mecklin $\mathrm{J}$, et al. Cancer risk in hereditary nonpolyposis colorectal cancer syndrome: later age of onset. Gastroenterology. 2005; 129(2): 41521.

174. National Cancer Institute [Internet]. Bethesda (MD): National Cancer Institute; 2012. Previous Version: SEER Cancer Statistics Review, 1975-2009 (Vintage 2009 Populations) [update 2012 Aug 20; cited 2019 Nov 1]. Available at: https://seer.cancer.gov/archive/ csr/1975_2009_pops09/.

175. Lynch HT, Smyrk TC, Watson P, Lanspa SJ, Lynch JF, Lynch PM, et al. Genetics, natural history, tumor spectrum, and pathology of hereditary nonpolyposis colorectal cancer: An updated review. Gastroenterology. 1993; 104(5): 1535-49.

176. De Vos tot Nederveen Cappel WH, Nagengast FM, Griffioen G, Menko FH, Taal BG, Kleibeuker JH, et al. Surveillance for hereditary nonpolyposis colorectal cancer.Dis Colon Rectum. 2002; 45(12): 1588-94.

177. Parry S, Win AK, Parry B, Macrae FA, Gurrin LC, Church JM, et al. Metachronous colorectal cancer risk for mismatch repair gene mutation carriers: the advantage of more extensive colon surgery. Gut. 2011; 60(7): 950-7.

178. Win AK, Parry S, Parry B, Kalady MF, Macrae FA, Ahnen DJ, et $a l$. Risk of metachronous colon cancer following surgery for rectal cancer in mismatch repair gene mutation carriers. Ann Surg Oncol. 2013; 20(6): 1829-36.

179. Win AK, Jenkins MA, Dowty JG, Antoniou AC, Lee A, Giles GG, et al. Prevalence and penetrance of major genes and polygenes for colorectal cancer. Cancer Epidemiol Biomarkers Prev. 2017; 26(3): 404-12.

180. Da Silva Fc, Wernhoff P, Dominguez-Barrera C, Dominguez-Valentin M. Update on hereditary colorectal cancer. Anticancer Res. 2016; 36(9): 4399-406.

181. Espenschied CR, LaDuca H, Li S, McFarland R, Gau CL, Hampel H. Multigene panel testing provides a new per- spective on Lynch syndrome. J Clin Oncol. 2017; 35(22): 2568-75.

182. Yamano T, Hamanaka M, Babaya A, Kimura K, Kobayashi M, Fukumoto M, Tsukamoto $\mathrm{K}$, et al. Management strategies in Lynch syndrome and familial adenomatous polyposis: a national healthcare survey in Japan. Cancer Sci. 2017; 108(2): 243-9.

183. Carethers JM, Stoffel EM. Lynch syndrome and Lynch syndrome mimics: the growing complex landscape of hereditary colon cancer. World J Gastroenterol. 2015; 21(31): 9253-61.

184. Wimmer K, Etzler J. Constitutional mismatch repair-defi- ciency syndrome: have we so far seen only the tip of the iceberg? Hum Genet. 2008; 124(2): 105-22.

185. Mensenkamp AR, Vogelaar IP, van Zelst-Stams WAG, Goossens M, Ouchene H, Hendriks-Cornelissen SJB, et al. Somatic mutations in MLH1 and MSH2 are a frequent cause of mismatch-repair deficiency in lynch syndrome-like tumors. Gastroenterology. 2014; 146(3): 643-6.e8.

186. Bettstetter M, Dechant S, Ruemmele P, Grabowski M, Keller G, Holinski-Feder E, et al. Distinction of hereditary nonpolyposis colorectal cancer and sporadic microsatellite-unstable colorectal cancer through quantification of MLH1 methylation by real-time PCR. Clin Cancer Res. 2007; 13(11): 3221-8.

187. National Comprehensive Cancer Network. NCCN Clinical Practice Guidelines in Oncology (NCCN Guidelines): Genetic/Familial High-Risk Assessment: Colorectal. USA: NCCN; 2017.

188. Kempers MJ, Kuiper RP, Ockeloen CW, Chappuis PO, Hutter P, Rahner N, et al. Risk of colorectal and endometrial cancers in EPCAM deletion-positive Lynch syndrome: a cohort study. Lancet Oncol. 2011; 12(1): 49-55.

189. Lynch HT, Riegert-Johnson DL, Snyder C, Lynch JF, Hagenkord J, Boland RC, et al. Lynch syndrome-associated extracolonic tumors are rare in two extended families with the same EPCAM deletion. Am J Gastroenterol. 2011; 106(10): 1829-36.

190. Giardiello FM, Allen JI, Axilbund JE, Boland CR, Burke CA, Burt RW, et al. US Multi-Society Task Force on Colorectal Cancer. Guidelines on genetic evaluation and management of Lynch syndrome: a consensus statement by the US Multi-Society Task Force on colorectal cancer. Gastroenterology. 2014; 147(2): 502 26.

191. Aarnio M, Sankila R, Pukkala E, Salovaara R, Aaltonen LA, de la Chapelle A, et al. Cancer risk in mutation carriers of DNAmismatch-repair genes. Int J Cancer. 1999; 81(2): 214-8.

192. Kastrinos F, Stoffel EM, Balmaña J, Steyerberg EW, Mercado R, Syngal S. Phenotype comparison of mlh1 and msh2 mutation carriers in a cohort of 1,914 individuals undergoing clinical genetic testing in the United States. Cancer Epidemiol Biomarkers Prev. 2008; 17(8): 2044-51.

193. Win AK, Young JP, Lindor NM. Colorectal and other cancer risks for carriers and noncarriers from families with a DNA mismatch repair gene mutation: a prospective cohort study. J Clin Oncol. 2012; 30(9): 958-64.

194. Axilbund JE, Klein AP, Bacon JA. Risk of pancreatic cancer in he- reditary nonpolyposis colorectal cancer. Presented at: the 3rd Bien- nial Meeting of the International Society for Gastrointestinal Hereditary Tumours (InSiGHT); June 24-27, 2009; Dusseldorf, Germany.

195. Grindedal EM, Moller P, Eeles R, Stormorken AT, Bowitz-Lothe IM, Landro SM, et al. Germ-line mutations in mismatch repair genes associated with prostate cancer. Cancer Epidemiol Biomarkers Prev. 2009; 18(9): 2460-7.

196. Kastrinos F, Mukherjee B, Tayob N, Wang F, Sparr J, Raymond VM, 
et al. Risk of pancreatic cancer in families with Lynch syndrome. JAMA. 2009; 302(16): 1790-5.

197. Müller A, Edmonston TB, Corao DA, Rose DG, Palazzo JP, Becker $\mathrm{H}$, et al. Exclusion of breast cancer as an integral tumor of hereditary nonpolyposis colorectal cancer. Cancer Res. 2002; 62(4): 1014-9.

198. Vasen HF, Morreau H, Nortier JW. Is breast cancer part of the tumor spectrum of hereditary nonpolyposis colorectal cancer? Am J Hum Genet 2001; 68(6): 1533-5.

199. Walsh MD, Buchanan DD, Cummings MC, Pearson SA, Arnold ST, Clendenning $\mathrm{M}$, et al. Lynch syndrome-associated breast cancers: clinicopathologic characteristics of a case series from the colon cancer family registry. Clin Cancer Res. 2010; 16(7): 2214-24.

200. Buerki N, Gautier L, Kovac M, Marra G, Buser M, Mueller H, et al. Evidence for breast cancer as an integral part of lynch syndrome. Genes Chromosom Cancer. 2011; 51(1): 83-91.

201. Raymond VM, Mukherjee B, Wang F, Huang SC, Stoffel EM, Kastrinos F, et al. Elevated risk of prostate cancer among men with Lynch syndrome. J Clin Oncol. 2013; 31(14): 1713-8.

202. Kelsen DP, Daly JM, Kern SE, editors. Principles and practice of gastrointestinal oncology. 2nd ed. Philadelphia: Lippincott William and Wilkins; 2008.

203. Teruya-Feldstein J, Greene J, Cohen L, Popplewell L, Ellis NA, Offit $\mathrm{K}$. Analysis of mismatch repair defects in the familial occurrence of lymphoma and colorectal cancer. Leuk Lymphoma. 2002; 43(8): 1619-26.

204. Nilbert M, Therkildsen C, Nissen A, Åkerman M, Bernstein I. Sarcomas associated with hereditary nonpolyposis colorectal cancer: broad anatomical and morphological spectrum. Fam Cancer. 2009; 8(3): 209-13.

205. Lynch HT, Lanspa S, Shaw T, Casey MJ, Rendell M, Stacey M, et al. Phenotypic and genotypic heterogeneity of Lynch syndrome: a complex diagnostic challenge. Fam Cancer. 2018; 17(3): 403-414.

206. Giardiello FM, Allen JI, Axilbund JE, Boland RC, Burke CA, Burt $\mathrm{RW}$, et al. Guidelines on genetic evaluation and management of lynch syndrome: a consensus statement by the US Multi-Society Task Force on Colorectal Cancer. Am J Gastroenterol. 2014; 109(8): 1159-79.

207. Fishel R, Lescoe MK, Rao MRS, Copeland NG, Jenkins NA, Garber $\mathrm{J}$, et al. The human mutator gene homolog MSH2 and its association with hereditary nonpolyposis colon cancer. Cell. 1993; 75(5): 102738 .

208. Kovacs ME, Papp J, Szentirmay Z, Otto S, Olah E. Deletions removing the last exon ofTACSTD1constitute a distinct class of mutations predisposing to Lynch syndrome. Hum Mutat. 2009; 30(2): 197-203.

209. Weissman SM, Belleross C, Bittner CC, Freivogel ME, Haidle JL, Kaurah $\mathrm{P}$, et al. Genetic counseling considerations in the evaluation of families for lynch syndrome-a review. J Genet Counsel. 2011; 20(1): 5-19.

210. Lee J, Ledermann JA, Kohn EC. PARP Inhibitors for BRCA1/2 mutation-associated and BRCA-like malignancies. Ann Oncol. 2014; 25(1): 32-40.

211. Link JT, Overman MJ. Immunotherapy progress in mismatch repairdeficient colorectal cancer and future therapeutic challenges. Cancer J. 2016; 22(3): 190-195. 